\title{
ANALISIS SEMIOTIKA HUKUM TERHADAP LAMBANG NEGARA REPUBLIK INDONESIA
}

\author{
Turiman ${ }^{1}$
}

\begin{abstract}
Through a semiotic analysis of the law the myth behind the text of the state law (Government Regulation No. 66 of 1951 and Act No. 24 of 2009) was able to be dismantled. Based on the analysis of the history of law, that the real symbol of the Republic of Indonesia in the semiotics of law is not a form of eagle Garuda in the mythology of Indonesia but it is a figure eagle Rajawali. Why the naming of the state emblem with the name of Garuda Pancasila. This proves that the semiotics of law is still strong against the mythology of Indonesia or still based on the legal history of early design state symbol that refers to the eagle sketches in various temples on the island of Java were sent Ki Hajar Dewantoro, January 26, 1950. However, based on historical analysis of the law, that forms an image of the proposed state symbol Sultan Hamid II dated February 8, 1950 in the form of an eagle holding a shield Pancasila symbol was rejected by the State Committee and subsequently was repaired by Sultan Hamid II by using the figure of an eagle Rajawali as eagle picture as a form today, or as an official form of picture becomes attachments Government Regulation Number 66 Year 1951 About Coat of States under Article 6 or now the attachment of Law Number 24 Year 2009 based on Article 50 despite the attachment of Law Number 24 Year 2009 was "engineered" by the state in some parts, as a symbol of natural cotton is made by drawing and writing different Unity in Diversity Unity in Diversity written form in the appendix of Government Regulation Number 66 Year 1951 or historical facts or law as a form of state symbol image specified by the Cabinet RIS February 11, 1950 and incorporated in the state news Parliament RIS No. 2 dated February 17, 1950 a further improved continuously by Sultan Hamid II based on the input of President Sukarno. Then the last repair existing picture size scale and full color, then the picture becomes official attachment Government Regulation Number 66 Year 1951 or as otherwise expressly stated by Muhammad Hatta, 1978 in response to the book Bung Hatta Answer, page 108 and 112.
\end{abstract}

Keywords: concept symbols, semiotics of law, state emblem

\begin{abstract}
Abstrak
Melalui analisis semiotika hukum ternyata mampu membongkar mitos dibalik teks hukum negara (Peraturan Pemerintah Nomor 66 Tahun 1951 dan Undang -Undang Nomor 24 Tahun 2009). Berdasarkan analisis sejarah hukum, bahwa sebenarnya lambang negara Republik Indonesia secara semiotika hukum
\end{abstract}

\footnotetext{
${ }^{1}$ Penulis adalah Staf Pengajar Fakultas Hukum Universitas Tanjungpura, Pontianak. Alamat kontak: turiman@untan.ac.id.
} 
adalah figur burung elang Rajawali bukan bentuk gambar figur burung garuda dalam mitologi bangsa Indonesia. Lalu mengapa terjadi penamaan lambang negara dengan nama Garuda Pancasila? Hal ini membuktikan bahwa secara semiotika hukum masih kuatnya terhadap mitologi bangsa Indonesia atau masih mendasarkan terhadap sejarah hukum awal perancangan lambang negara yang mengacu pada sketsa-sketsa burung garuda di berbagai candi di pulau Jawa yang dikirim Ki Hajar Dewantoro, 26 Januari 1950. Namun berdasarkan analisis sejarah hukum, bahwa bentuk gambar lambang negara yang diajukan Sultan Hamid II tanggal 8 Februari 1950 yang berbentuk burung garuda yang memegang perisai Pancasila sudah ditolak oleh Panitia Lambang Negara dan selanjutnya sudah diperbaiki oleh Sultan Hamid II dengan menggunakan figur elang Rajawali sebagaimana bentuk gambarnya sekarang ini, atau sebagaimana bentuk gambarnya menjadi lampiran resmi Peraturan Pemerintah Nomor 66 Tahun 1951 tentang Lambang Negara berdasarkan Pasal 6 atau sekarang menjadi lampiran Undang-Undang Nomor 24 Tahun 2009 berdasarkan Pasal 50 walaupun dalam lampiran UndangUndang Nomor 24 Tahun 2009 ada "rekayasa" oleh negara dalam beberapa bagian, seperti lambang kapas dibuat berdasarkan gambar alamiah dan bentuk tulisan Bhinneka Tunggal Ika berbeda dengan bentuk tulisan Bhinneka Tunggal Ika dalam lampiran Peraturan Pemerintah Nomor 66 Tahun 1951 atau secara fakta sejarah hukum sebagai bentuk gambar lambang negara yang ditetapkan oleh Kabinet RIS 11 Februari 1950 dan dimasukkan dalam berita negara Parlemen RIS nomor 2 tanggal 17 Februari 1950 yang selanjutnya diperbaiki terus menerus oleh Sultan Hamid II berdasarkan masukan Presiden Soekarno. Kemudian perbaikan terakhir kali gambarnya yang ada skala ukuran dan tata warna, selanjutnya gambar tersebut menjadi lampiran resmi Peraturan Pemerintah Nomor 66 Tahun 1951 atau sebagaimana dinyatakan secara tegas oleh Muhammad Hatta, 1978 dalam buku Bung Hatta Menjawab halaman 108 dan 112

Kata Kunci: Konsep Simbol, Semiotika Hukum, Lambang Negara.

\section{Pendahuluan}

\section{Latar Belakang}

Mencari kebenaran adalah esensi filsafat hukum, sedangkan kebebasan menjadi ruh untuk berfilsafat hukum. Karena itu, banyak filsuf yang hanya melayang-layang saja, meneliti berbagai hal yang mungkin tidak pasti serta terus mencari dalam kebebasannya tanpa fakta hukum yang mendukung kebenarannya. Karena itu, pada dasarnya filsafat hukum tidak pernah sampai pada sintesis, namun hanya akan membentuk lingkaran ilmu pengetahuan yang berpusar pada tesis dan antitesis seiring berdetaknya sejarah waktu. Salah satu metode untuk mengungkap kebenaran adalah melalui pendekatan sejarah hukum. Tujuan akhir dari penelitian disertasi ini adalah mengungkap kebenaran penelitian sejarah 
hukum dengan analisis semiotika hukum yang lebih komprehensif terhadap Lambang Negara Republik Indonesia, namun juga mengajukan rancang bangun konsep/model pembacaan Pancasila berdasarkan Lambang Negara melalui metode semiotika hukum.

Penelitian sejarah hukum memerlukan ruang kesadaran pemikiran yang kemudian dikenal kesadaran sejarah. Untuk itulah penelitian sejarah hukum dalam ranah studi hukum tata negara memerlukan bukti sejaman sebagai record memory. Perjalanan sejarah perancangan Lambang Negara Republik Indonesia hampir sama setara usianya dengan perjuangan bangsa ini mengisi kemerdekaan. Selama itu pula, pengetahuan publik dan para pentudi hukum redup jika dibandingkan siapa penjahit bendera merah putih dan pencipta lagu kebangsaan atau dalam perspektif hukum tata negara sejarah hukum lambang negara Republik Indonesia "tersembunyikan" oleh negara. Sedangkan pada sisi lain Pancasila yang divisualisasikan dalam Perisai Pancasila belum pernah dianalisis secara semiotika hukum. Pancasila selama ini ada kecenderungan "dimitoskan" hanya sebagai produk sejarah filsafat bangsa Indonesia.

Sudah terlalu lama bangsa ini "menyembunyikan fakta sejarah" proses perancangan lambang negara, yakni 63 Tahun (11 Februari 19502013) dan analisis studi hukum hubungan lambang negara dengan Pancasila. Pada tahun 1978 Muhammad Hatta menyatakan secara tegas, bahwa yang membuat lambang negara Republik Indonesia adalah Sultan Hamid II dan lambang negara tersebut ditetapkan oleh Dewan Menteri RIS tanggal 11 Februari 1950 dan disahkan Parlemen RIS 17 Februari 1950, sedangkan lambang negara Muhammad Yamin ditolak karena ada sinar-sinar matahari sedikit banyak pengaruh Jepang. ${ }^{2}$ Pernyataan Muhammad Hatta ini menimbulkan pro dan kontra, karena pada satu sisi belum terungkap dokumen file lambang negara yang dimaksudkan Muhammad Hatta secara lengkap, sementara dugaan yang berkembang di publik yang membuat adalah Muhammad Yamin. Pada tataran teks hukum negara (Undang-Undang Nomor 24 Tahun 2009) sebagai pelaksanaan Pasal 36 C UUD Negara RI 1945 selama ini belum menegaskan nama perancang lambang negara Republik Indonesia yang bentuk gambarnya sekarang ini (pasal 46). Hal ini berbeda ketika teks hukum negara merumuskan lagu kebangsaan (pasal 58)

Ketidaktegasan negara dalam undang-undang tersebut menimbulkan diskriminasi hukum, sedangkan hukum negara seharusnya tidak mengandung diskriminasi hukum pada tataran konstitusi negara (pasal 28D ayat (1), 28 I ayat (2) UUD Neg RI 1945). Pada sisi lain terjadi perbedaan antara teks hukum negara dengan dokumen file lambang negara sebagai fakta sejarah hukum. Hal ini menarik dari sisi studi hukum dengan pendekatan semiotika hukum untuk mendukung

\footnotetext{
${ }^{2}$ Muhammad Hatta, "Bung Hatta Menjawab", (Jakarta: Gunung Agung, 1978), hal., 108 dan 112.
} 
kebenaran sejarah hukum lambang negara Republik Indonesia. Kemudian dari sisi teoritik dilakukan dekonstruksi terhadap pembacaan Pancasila yang masih "terbelenggu" dengan pembacaan Pancasila hirarkis piramida ketika menempatkan Pancasila sebagai cita hukum bangsa Indonesia, karena selama ini mengacu pandangan Notonagoro, 1955 yang mengemukakan pembacaan Pancasila hirarkis piramida. Sedangkan sejak Tahun 1950 konsep pembacaan Pancasila tidaklah hirarkis piramida tetapi berputar berlawanan dengan arah jarum jam atau "berthawaf"/Gilir Balik' sebagaimana terpaparkan secara semiotika hukum lambang negara pada perisai Pancasila. Konsep pembacaan Pancasila hirarkis piramida menimbulkan problematika filsafat hukum dan tataran teoritik terhadap kaitannya dengan Pancasila sebagai cita hukum, karena pembacaan belum berdasarkan Lambang Negara. Mengapa terjadi demikian? Sedangkan antara lambang negara dengan Pancasila mempunyai hubungan yang bersifat tidak terpisahkan tetapi terbedakan sebagaimana dinyatakan secara tegas oleh Presiden Soekarno 22 Juli 1958.

Kemudian dari sisi hukum hak cipta adalah bagaimana perlindungan hukum terhadap perancang lambang negara atau dengan kata lain mengapa dalam teks hukum negara (Undang-undang Nomor 24 tahun 2009) terjadi diskriminasi hukum antara teks hukum tentang lambang negara dengan lagu kebangsaan, apakah karena akibat belum jelasnya tentang sejarah hukum perancangan lambang negara secara ilmiah atau ada faktor lain yang mengakibatkan negara belum tegas terhadap siapa yang merancang lambang negara sebagaimana bentuk gambarnya seperti sekarang ini. Pada akhirnya perlu ada penelitian mendalam terhadap sejarah hukum perancangan lambang negara sebagai bahan lembaga negara untuk menegaskan hal tersebut.

Untuk itu peneliti tertarik untuk meneliti lebih mendalam terhadap sejarah hukum dengan metode historis yuridis dan metode semiotika hukum. Mengacu pada dua hasil penelitian dengan kedua metode tersebut kemudian menghubungkan pembacaan Pancasila sebagai cita hukum dengan menggunakan konsep pembacaan Pancasila berdasarkan lambang negara Republik Indonesia dan membuat rancang bangun model pembacaan Pancasila berdasarkan lambang negara dengan melakukan korelasi horizontal antara Undang-Undang Nomor 24 tahun 2009 (pasal 48 ayat (2) dengan Undang-Undang Nomor 12 tahun 2011 (pasal 6).

\section{Metode Penelitian}

Penelitian ini memilih metode penelitian hukum ${ }^{3}$ bertipe kualitatif yang berbasiskan penelitian ilmu hukum, yaitu studi keilmuan ${ }^{4}$ dengan

\footnotetext{
${ }^{3}$ Metode Penelitian Hukum disini dimaksudkan adalah proses penelitian dan menurut Suteki, bahwa proses penelitian, bukan metode penelitian karena dalam sebuah penelitian seorang peneliti perlu memperhatikan beberapa aspek penelitian bukan hanya metode
} 
menggunakan dua metode, yaitu (1) historis yuridis dalam ilmu hukum tata negara dengan pendekatan analisis sejarah hukum terhadap sejarah hukum perancangan lambang negara Republik Indonesia dan (2) metode semiotika dengan pendekatan analisis semiotika hukum. ${ }^{5}$ Metode

penelitiannya. Beberapa aspek pendukung sebuah penelitian tersebut yaitu: Tradisi Penelitian, Paradigma Penelitian, Pendekatan Penelitian dan Metode Penelitian, dan peneliti harus menarik benang merah antara tradisi, paradigma, pendekatan dan metode penelitian dan peneliti dituntut memahami seluk beluk problem yang diajukan baik dari aspek filosofis sampai aspek praktikalnya, oleh karena itu penelitian dalam ilmu hukum memiliki obyek berupa hukum yang bersifat complek dan complecated. Suteki, Urgensi Tradisi Penelitian Dalam Proses Penelitian Ilmiah, Makalah Seminar Nasional Metodologi Penelitian Dalam Ilmu Hukum di selenggarakan oleh Bagian Hukum Dan Masyarakat Fakultas Hukum Universitas Diponegoro, Semarang 16 Desember 2010, hal. 1-2. Sedang Studi keilmuan dimaksudkan disini adalah penelitian ini tidak hanya bertumpu pada teks kenegaraan yang terdapat dalam peraturan perundang-undangan atau dalam ilmu hukum Tata Negara disebut kajian yuridis formal, memasuki tataran yang paling abstrak, yaitu filsafat hukum yang memiliki tugas mencari hakekat hukum yang merefleksikan secara umum dengan arah pada asas kebenaran dan keadilan, yang kemudian diturunkan menjadi teori hukum yang bercorak meta ilmu hukum bertugas memberikan penjelasan atas berbagai konsep hukum tanpa harus terikat pada bangunan sistem hukum tertentu. Konsep -konsep inilah yang nanti sangat berguna untuk menunjang kegiatan penemuan hukum (rechtsvinding). Jadi Teori hukumnya bersifat interdisipliner, dan pada tataran ini dijadikan "pintu masuk" untuk bersinergi dengan ilmu-ilmu lain diluar disiplin hukum, bukan pada tataran ilmu hukum dogmatis, dan pintu masuk disini yang dimaksudkan adalah pendekatan non disiplin hukum, seperti sejarah hukum, semiotika hukum, psikologi hukum, dan hermenuetika hukum. Sidharta, Penelitian Dalam Perspektif Normatif, Makalah Seminar Nasional Metodologi Penelitian Dalam Ilmu Hukum, diselenggarakan oleh Bagian Hukum Dan Masyarakat Fakultas Hukum Universitas Diponegoro, Semarang, 16 Desember 2010, hal. 7.

${ }^{4}$ Pada Penelitian Ilmu Hukum bisa dijelaskan ada dua kategori yang berbeda: Pertama, sebagai studi normatif yang obyeknya adalah hukum yang dikonsepsikan didalam kehidupan masyarakat. Penelitian yang dilakukan adalah untuk mengetahui kaidah-kaidah hukum yang seharusnya berlaku dan sebaliknya. Kedua, sebagai studi keilmuan yang bermaksud menyingkap dan mencari kebenaran (searching and revealing the truth) didalam kategori yang kedua ini studi hukum bermaksud untuk menjelaskan (explanation), mengkritik, dan selanjutnya menyusun suatu ketentuan baru, atau membangun teori (theory building), oleh karena ada dua kategori penelitian ilmu hukum, maka cara mempelajari dan mengkonsepsikan apa yang dimaksud dengan hukumpun juga berbeda. Adji Samekto, "Justice Not For All", (Yogyakarta: Genta Press, 2008), hal. 2.

5 Analisis semiotika adalah metode penelitian untuk menafsirkan makna dari suatu pesan komunikasi baik yang tersirat (tertulis) maupun yang tersurat (tidak tertulis/terucap). Makna yang dimaksud mulai dari parsial hingga makna komprehensif. Sehingga dapat diketahui motif komunikasi dari komunikatornya. Metode semiotika dikembangkan untuk menafsirkan simbol komunikasi sehingga dapat diketahui bagaimana komunikator mengkontruksi pesan untuk maksud-maksud tertentu. Untuk memahami metode analisis semiotika dapat dilihat dalam Aminuddin, "Semantik: Pengantar Studi tentang Makna", (Bandung: Sinar Baru 1988), Manneke Budiman , "Indonesia: Perang Tanda," dalam Indonesia: Tanda yang Retak, (Jakarta: Wedatama Widya Sastra, 2002), de De de Saussure, F., "Course in General Linguistics", (Yogyakarta: Gajah Mada University Press, 1988), Benny H. Hoed, "Strukturalisme, Pragmatik dan Semiotik dalam Kajian Budaya,", Mansoer Pateda, 2004, "Semantik Leksikal", (Jakarta: Rineka Cipta, 2001), Alex Sobur, "Analisis Teks Media", (Bandung: Remaja Rosdakarya, 2002), A.Teew, "Khasanah Sastra Indonesia", 
semiotika dimaksud di sini adalah metode untuk menganalisa lebih lanjut terhadap hasil penelitian sejarah hukum sebelumnya yang menggunakan metode historis yuridis dalam ilmu hukum tata negara.

Mengapa menggunakan dua pendekatan sekaligus, yaitu pendekatan sejarah hukum dan pendekatan semiotika hukum, karena pada penelitian ilmu hukum termasuk dalam ilmu hukum tata negara, bisa dijelaskan ada dua kategori penelitian yang berbeda: Pertama, sebagai studi normatif yang obyeknya adalah hukum yang dikonsepsikan di dalam kehidupan masyarakat. Penelitian yang dilakukan adalah untuk mengetahui kaidahkaidah hukum yang seharusnya berlaku dan sebaliknya. Kedua, sebagai studi keilmuan yang bermaksud menyingkap dan mencari kebenaran (searching and revealing the truth) di dalam kategori yang kedua ini studi hukum bermaksud untuk menjelaskan (explanation), mengkritik, dan selanjutnya menyusun suatu ketentuan baru, atau membangun teori (theory building), oleh karena ada dua kategori penelitian ilmu hukum, maka cara mempelajari dan mengkonsepsikan apa yang dimaksud dengan hukum pun juga berbeda. ${ }^{6}$

Berdasarkan dua kategori penelitian hukum di atas, maka peneliti memilih kategori yang kedua, yaitu studi keilmuan dengan tanpa mengabaikan teks hukum negara yang terdapat dalam peraturan perundang-undangan yang berkaitan dengan pengaturan lambang negara. Adapun alasannya: (1) karena penelitian ini bermaksud menyingkap dan mencari kebenaran terhadap fakta sejarah hukum yang berkaitan dengan proses sejarah perancangan lambang negara oleh Sultan Hamid II sebagaimana pernyataan Muhammad Hatta, 1978, (2) Penelitian bermaksud menjelaskan secara semiotika hukum terhadap pemilihan lambang negara oleh bangsa Indonesia dan pembacaan terhadap Pancasila pada perisai Pancasila berdasarkan lambang negara, (3) Mengkritik dan selanjutnya menyusun ketentuan baru, yaitu revisi Undang-Undang Nomor 24 tahun 2009, khususnya antara Pasal 48 dengan pasal 58 yang bersifat diskriminasi hukum, (4) Melakukan analisis semiotika hukum antara teks hukum negara dalam peraturan perundangan-undangan yang berkaitan dengan lambang negara dengan fakta sejarah hukum lambang negara, karena ada perbedaan antara teks hukum negara dalam peraturan perundang-undang dengan fakta dokumen file lambang negara berdasarkan hasil penelitian sejarah hukum lambang negara, (5) Pada akhirnya dengan menggunakan kedua pendekatan tersebut dimaksudkan mengajukan model/konsep baru terhadap pembacaan Pancasila berdasarkan lamba ng negara, (6) Selanjutnya pada bagian terakhir mengkaitkan analisis terhadap Pancasila sebagai cita hukum Indonesia dalam tataran teoritik selama ini oleh para penstudi

(Jakarta: Balai Pustaka, 1984), Aart Van Zoest, "Semiotika: Tentang Tanda, Cara Kerjanya dan Apa yang kita Lakukan Dengannya”, (Jakarta: Yayasan Sumber Agung, 1993).

${ }^{6}$ Adji Samekto, “Justice Not For All”, (Yogyakarta: Genta Press, 2008), hal. 2. 
hukum Indonesia dengan model pembacaan Pancasila berdasarkan yang menggunakan konsep hirarkis piramida, (7) Menyusun rancang bangun terhadap model Pembacaan Pancasila berdasarkan lambang negara dalam kapasitas Pancasila sebagai cita hukum Indonesia berdasarkan paradigma pemikiran hukum yang dipilih oleh peneliti.

Berdasarkan kedua metode analisis yang dipilih dalam penelitian ini, teknik pengumpulan data melalui teknik studi dokumenter, yaitu peneliti melakukan pengumpulan data melalui penelusuran transkrip dan sketsa-sketsa dalam bentuk repro dokumen file lambang negara yang berkaitan dengan sejarah hukum lambang negara baik rancangan lambang negara dari Sultan Hamid II dan Muhammad Yamin dari berbagai sumber, yaitu:

1. Yayasan Idayu, Jakarta;

2. Yayasan H. Mas Agung, Jakarta;

3. Yayasan Sultan Hamid II, Jakarta.

Data juga didapatkan melalui sumber perorangan, yaitu orang-orang yang pernah menyimpan dan pernah melakukan investigasi terhadap keberadaan file lambang negara Republik Indonesia selama ini, yaitu:

1. U'un Masdar Asmadi, UNPAD Bandung, 1985;

2. Akmal Sutja, IKIP Jambi,1986;

3. Dewan Redaksi Majalah Intisari No. 205 "Garuda Pancasila Siapa Penciptanya” Agustus 1980, Elang-Elang Lambang Negara, Majalah Intisari cetakan I, 1995, Jakarta;

4. A.B Kusuma, sejarawan Konstitusi Universitas Indonesia yang menyimpan buku Lukisan Revolusi Indonesia, 1949-1950 terbitan Kementerian Penerangan Republik Indonesia. Buku ini berkaitan dengan dokumen foto lukisan lambang negara rancangan Sultan Hamid II yang dilukis untuk terakhir kalinya oleh pelukis Istana Dullah atas perintah Presiden Soekarno, Maret 1950;

5. Safarudin Usman, sejahrawan Buletin Mimbar Universitas Tanjungpura Pontianak, 1994, yang menemukan repro lambang negara hasil disposisi Presiden Soekarno, 20 Maret 1950 di Istana Kadriah Pontianak;

6. Nanang Hidayat, Pengelola Rumah Garuda, Yogyakarta, 2010 dan peneliti tesis "Mencari Telur Garuda" Program Magister Sastra, UGM, 2008, sebagai penyimpan hasil sayembara lambang negara yang dilaksanakan Kementrian Penerangan tahun 1947;

7. Ibu K. Irawati, 1967, sebagai penyimpan dokumen foto asli Lambang Negara yang kaki cakarnya yang mencekram pita bertuliskan Bhinneka Tunggal Ika menghadap kebelakang (sekarang dokumen foto tersebut berada di Yayasan Sultan Hamid II, Jakarta);

8. Max Yusuf Al-Kadrie, 1972, sebagai penyimpan sebagian dokumen lambang negara asli rancangan Sultan Hamid II yang di dalamnya terdapat disposisi Presiden Soekarno 20 Maret 1950 kepada Sultan Hamid II selaku Menteri Negara RIS dan dokumen, foto penyerahan 
file lambang negara kepada H. Mas Agung Yayasan Idayu, Jakarta, 18 Juli 1974, serta transkrip Sultan Hamid II, 15 April 1967 yang ditujukan kepada Solichim Salam wartawan Istana dan wartawan Berita Buana Jakarta. Patut diketahui, bahwa dokumen-dokumen tersebut tidak turut diserahkan ke Yayasan Idayu, Jakarta 18 Juli 1974 sebagaimana amanah/wasiat Sultan Hamid II.

Selain itu peneliti juga melakukan teknik studi kepustakaan, meliputi data-data literatur yang berkaitan dengan fokus penelitian ini serta data-data teks hukum negara, yaitu peraturan perundang-undangan yang berkaitan dengan pengaturan lambang negara untuk disandingkan dengan data file dokumen lambang negara. Teknik lain yang cukup signifikan dengan kedua pendekatan penelitian ini, adalah melalui gelar forum ilmiah, yaitu dalam bentuk teknik diskusi terfokus, pameran lambang negara dan presentasi serta seminar nasional dan daerah tentang sejarah hukum lambang negara melalui fasilisasi Yayasan Sultan Hamid II Jakarta dengan berbagai kelembagaan yang berkepentingan terhadap penelitian ini dengan menghadirkan sejarawan, ahli semiotika, pengamat sejarah dan kehidupan kenegaraan, Guru sejarah, mahasiswa di lima tempat, Bandung, Jakarta, Yogyakarta, Sintang dan Pontianak. Kemudian terakhir peneliti melakukan wawancara terstruktur langsung dan melalui $e$-mail kepada sejumlah narasumber yang pernah melakukan investigasi data file dokumen lambang negara Republik Indonesia dari tahun 1985 sampai dengan penelitian ini berakhir yang kemudian hasil wawancara tersebut dipadukan dengan data penelitian peneliti dari tahun 1999 sampai penelitian ini berakhir.

\section{Kerangka Teori}

\section{a. Konsep Simbol dalam Semiotika}

Sebelum membicarakan lambang negara sebagai simbol kenegaraan dari sisi semiotika hukum, terlebih dahulu diuraikan pengertian simbol itu sendiri, serta fungsi dan pemakaian simbol itu dalam kehidupan manusia. Pemahaman tentang simbol akan mempermudah pemahaman kita terhadap lambang negara, karena lambang negara adalah salah satu atribut kenegaraan hasil kreativitas manusia.

Menguraikan simbol secara jelas membutuhkan kecermatan dan cakrawala berpikir yang luas, karena simbol itu berdampingan dengan tanda-tanda lain yang sangat mirip dengannya. Tanda-tanda itu sering disalahtafsirkan atau disamakan, baik oleh masyarakat maupun oleh pakar-pakar psikologi, antropologi, seni, linguistic, dan sastra. Tanda-tanda yang penulis maksudkan adalah simbol (symbol), tanda (sign), sinyal (signal), gerak isyarat (gesture), gejala (symptom), kode (code), indeks (index), dan gambar (icon). 
Semua istilah di atas, menurut Charles Sanders Peirce, merupakan obyek bidang semiotika atau menurut istilah Ferdinand de Saussure disebut semiologi. Namun, sering sekali para pakar semiotika (semiologi) mempunyai istilah yang berbeda-beda untuk menyatakan konsep atau ide yang sama. Dengan kata lain, satu konsep pikiran diistilahkan dengan berbagai nama, tetapi dengan uraian atau batasan yang sama atau hampir sama.

Barber dalam bukunya The Story of Language, Gordon dalam bukunya The Language of Communication, Cassirer dalam bukunya An Essay on Man masing-masing membedakan antara simbol (symbol) dan tanda (sign), yaitu berturut-turut dengan pembedaan antara arbitrer conventional secara alamiah, antara abstrak-konotatifkontemplatif secara konkret, dan antara bahasa proposional dengan bahasa emosional atau antara dunia manusia dengan dunia hewan.

Saussure dalam bukunya Course in General Linguistics menggunakan istilah tanda (sign), tetapi yang dia maksudkan sesuai dengan penjelasannya, sama dengan pengertian simbol. Zoest dalam bukunya Semiotiek mengatakan bahwa keseluruhan istilah di atas tersebut adalah tanda (teken), yang walaupun dalam pembicaraan selanjutnya yaitu mengenai semiotic kesusastraan (literatuursemiotiek), dia membagi tanda, sesuai dengan pendapat Peirce, menjadi; tanda simbolis (symbolische tekens) tanda indeksis (indexical tekens) dan tanda ikons (iconsche tekens).

George Herbert Mead cenderung membedakan antara simbol adalah bentuk komunikasi yang paling dominan dalam interaksi sosial manusia, sedangkan gerak isyarat merupakan bentuk komunikasi yang dominan dalam interaksi sosial hewan.

Menurut penulis sebaiknya, ada pembatasan yang jelas dan tegas, baik berupa definisi maupun berupa uraian yang membedakan antara istilah yang satu dengan istilah yang lain. Pembedaan dan pengklasifikasian istilah itu akan lebih mudah masuk ke dalam pikiran kita. Ketidaktegasan definisi istilah untuk menyatakan suatu konsep pikiran akan mengaburkan istilah dan konsep itu sendiri.

Memang, apabila kita berbicara mengenai simbol secara tegas dengan membedakannya dengan istilah-istilah tanda lain, tampaknya selalu timbul beberapa pertanyaan atau persoalan lain yang seolaholah eksklusif, tetapi seyogyanya inklusif atau sebaliknya. Hal itu juga dialami oleh Fromm yang mencetuskannya dalam tulisannya yang berjudul The Nature of Symbolic Language dengan berkata : "Simbol itu apa ? Simbol sering didefinisikan sebagai sesuatu yang mewakili yang lain." Definisi ini tampaknya agak mengecewakan. Walaupun begitu, lebih menarik lagi apabila kita memusatkan perhatian pada simbol-simbol yang merupakan ungkapan indrawi seperti melihat, mendengar, mencium, menyentuh, yang merepresentasikan sesuatu yang lain, yang merupakan pengalaman batiniah yaitu perasaan atau pikiran. Jenis simbol seperti ini adalah 
sesuatu yang berada di luar diri kita sedangkan yang disimbolkannya adalah sesuatu yang berada dalam diri kita sendiri. ${ }^{7}$

Simbol atau lambang adalah sesuatu yang dapat melambangkan mewakili ide, pikiran, perasaan, benda, dan tindakan secara arbitrer, conventional, dan representatif-interpretatif. Dalam hal ini, tidak ada hubungan langsung dan alamiah antara yang melambangkan (menyimbolkan) dengan yang dilambangkan (disimbolkan). Dengan demikian, baik yang batiniah (inner) seperti perasaan, pikiran, ide maupun yang lahiriah (outer) seperti benda dan tindakan dapat dilambangkan atau diwakili simbol. ${ }^{8}$

Contohnya adalah lambang-lambang dari pemerintah daerah di Indonesia, pada tataran semiotik sebenarnya memaparkan karakteristik masing-masing daerah, mengapa demikian? karena gambarnya (ikon)-nya diambil dari benda-benda fisik yang bisa melambangkan atau mewakili ide, perasaan dan karakteristik daerah itu sendiri. Pertanyaannya, mengapa selalu mengambil ikon dari daerah yang bersangkutan?

Alasan pertama adalah karena simbol itu dibentuk secara arbitrer. Pemakai simbol tidak perlu banyak berpikir untuk menentukan tanda apa yang akan dia gunakan untuk menyimbolkan sesuatu benda, tindakan, perasaan, pikiran atau ide. Simbol apapun dapat digunakan untuk melambangkan yang dilambangkan. Hanya saja, alasan kedua perlu diperhatikan untuk mengesahkan simbol yang arbitrer itu. Perlu ada konvensi yaitu suatu kesepakatan, perjanjian atau pemufakatan masyarakat pemakai simbol. Apabila dalam proses penciptaan secara arbitrer dapat dikatakan simbol bersifat individual, maka dalam proses pemufakatan masyarakat pemakai simbol, maka dalam proses pemufakatan ia bersifat sosial.

Berdasarkan kedua alasan di atas, maka alasan berikutnya simbol itu harus dirasionalisasi, yaitu simbol itu mampu merepresentasikan yang diwakilinya secara tepat. Kemampuan representatif simbol itu dapat diuji dengan alasan berikutnya yaitu interpretasi dari individu atau kelompok masyarakat pemakai simbol itu. Dengan kata lain, sebuah simbol dapat diklasifikasi sebagai simbol apabila mampu merepresentasikan yang dilambangkannya berdasarkan interpretasi penafsiran simbol itu.

Hubungan interpretasi dengan representasi tidak dapat dipisahkan antara yang satu dengan yang lain sebagaimana yang dikatakan oleh Zoest. ${ }^{9}$ Hubungan yang tidak dapat dilepaskan dari

${ }^{7}$ Erich Fromm, 1951."The Nature of Symbolic Language". Dalam Arthur M. Eastman (Ed.). The Norton Reader. An Anthology of Expository Prose. (New York: Norton and Company, 1978), hal. 194.

${ }^{8}$ Ibid., hal. 195. 
sifat representatif tanda (dalam hal ini juga simbol) adalah sifat interpretatif.

Sebuah simbol dapat diinterpretasikan secara ganda atau lebih daripada satu makna (muli-interpretable) sehingga dengan sendirinya mempunyai representasi ganda (multi-representation), baik dalam lingkungan yang sama maupun dalam lingkungan yang berbeda. Gambar pohon beringin, misalnya, merupakan simbol salah satu partai di Indonesia yaitu Partai Golongan Karya, sedangkan bagi masyarakat Batak Toba pohon beringin itu merupakan lambang kepercayaan. Simbol (+) juga dapat diinterpretasikan secara umum ke dalam tiga makna dan sekaligus tiga representasi. Pertama, simbol itu dapat menandakan penambahan sebagai lawan pengurangan dalam matematika. Kedua, itu merupakan simbol keselamatan bagi orang Kristen yang diistilahkan dengan salib. Ketiga, simbol itu digunakan sebagai lambang pertolongan kesehatan, peperangan, dan bencana alam dalam organisasi yang disebut Palang Merah.

Representasi dan interpretasi simbol dapat bersifat denotatif dan konotatif. Pengertian denotasi dan konotasi di sini adalah suatu deretan interpretasi simbol secara bertingkat. Dengan kata lain, denotasi merupakan dasar interpretasi pada konotasi, sedangkan konotasi adalah interpretasi baru berdasarkan makna baru atau setelah denotasi.

Simbol secara filosofis sesungguhnya mewakili ide, perasaan, pikiran, benda, dan tindakan. Dengan demikian, simbol merupakan wadah ide, perasaan, pikiran, benda dan tindakan. Itulah kandungan simbol. Isi itu ditransformasikan secara konvensional dan arbitrer ke dalam suatu wadah yang disebut simbol tanpa ada hubungan langsung antara isi dengan wadahnya. Simbol mampu melingkupi dan merepresentasikan keseluruhan ide, perasaan, pikiran, benda dan tindakan. Proses penyimbolan itu disebut simbolisme.

Setelah menguraikan simbol di atas secara panjang lebar, maka pada bagian ini akan dijelaskan perbedaan antara simbol dengan tanda (sign). Perbedaan yang paling nyata adalah bahwa tanda (sign) tidak bersifat arbitrer dan konvensional, tetapi ada hubungan langsung dan alamiah antara penanda dengan petandanya. Perbedaan ini dijelaskan oleh Barber ${ }^{10}$ dalam bukunya The Story of Language dengan membuat ilustrasi yang diambil dari tanda lalu lintas di Inggris. Gambar atau tanda lalu lintas pertama menunjukkan dua orang anak-anak yang sedang berlari ke jalan; gambar itu bersifat bersifat represensional, karena dapat memberikan gambar aktual tentang adanya yang membahayakan di depan pengendara dan makna gambar itu tidak perlu dijelaskan kepada pengendara. Yang kedua menunjukkan obor yang menyala; gambar itu mewakili

\footnotetext{
${ }^{9}$ Aart van Zoest, “Semiotiek”, (Belgia: Basisboeken/Ambo/Baarn, 1978), hal. 22.

${ }^{10}$ Barber C.L., “The Story of Language”, (London: The Chaucer Press, 1972), hal.18
} 
pengetahuan. Gambar itu dapat memberitahukan bahwa ada sekolah di depan, tetapi hubungan antara sebuah obor yang menyala dengan pengetahuan bersifat arbitrer dan maknanya perlu dijelaskan kepada pengendara. Obor yang menyala itu adalah suatu simbol.

Ashley Montagu melihat perbedaan antara simbol dengan tanda. Dia menjelaskan bahwa tanda (sign), menurut Gordon, ${ }^{11}$ adalah suatu penunjuk yang konkret; tanda itu mengisyaratkan, "ini dia, lakukan sesuatu terhadapnya". Sebaliknya, simbol adalah internal. Tanda adalah eksternal (tetap). Simbol adalah abstrak, konotatif, kontemplatif, penuh arti, dan banyak pengetahuan di dalamnya.

Tanda adalah eksternal. Simbol adalah internal. Tanda sangat berhubungan dengan dunia alamiah, sedangkan simbol dengan dunia ide. Simbol adalah makna abstrak dari suatu nilai yang diberikan oleh mereka yang menggunakannya terhadap sesuatu yang lain, baik yang nyata maupun tidak. Sebaliknya, tanda adalah suatu benda fisik yang dimengerti sebagai sesuatu yang mewakili yang lain.

Istilah ketiga perlu mendapat perhatian dalam pembicaraan ini adalah sinyal atau isyarat. Sinyal hampir sama dengan tanda dalam pengertian di atas, tetapi sinyal lebih menunjuk, memberitahukan atau mengisyaratkan yang diwakilinya kepada penerima sinyal. Sinyal berbeda juga dari simbol, karena sinyal tidak menuntut interprestasi dari penerima isyarat tersebut tetapi lebih menuntut perhatian dari penerimanya. Isyarat biasanya bersifat imperatif yang diikuti oleh respons yang berupa tindakan atau sekedar permahaman.

Sinyal tampaknya cenderung merupakan sistem komunikasi satu arah (one-way communication) sehingga si pemberi sinyal tidak begitu membutuhkan respons yang sama, tetapi hanya respons untuk memahami atau mematuhi sinyal tersebut. Tembakan pistol tiga kali (atau lebih) pada pertandingan renang atau lomba lari adalah sinyal atau isyarat untuk menandakan permulaan perlombaan kepada para peserta.

Untuk lebih jelasnya, dapat dikatakan bahwa sinyal adalah sesuatu yang dapat mengisyaratkan dan juga mewakili ide, pikiran, perasaan, benda dan tindakan secara imperatif dengan maksud untuk dapat menimbulkan perhatian si penerima sinyal.

Apabila lampu sein (lampu tangan) sepeda motor seseorang tidak hidup, maka dia membentangkan tangannya sebagai pengganti lampu sein itu untuk menunjuk arah yang akan dia ambil kepada pengendara dari depan atau dari belakangnya. Gerak tangan dan dan lampu sein itu disebut juga sinyal.

Lalu timbul pertanyaan, bukankah gerak tangan seperti diuraikan di atas termasuk gerak-isyarat (gesture)? Kita akan

\footnotetext{
${ }^{11}$ George N. Gordon, “The Languages Communication”, (New York: Hasting House Publishers, 1969), hal. 54.
} 
menjawabnya dengan tidak. Memang, dia menggunakan gerak tangan, tetapi dia mengisyaratkan sesuatu yaitu arah yang akan di ambil dan cenderung mengharapkan agar penerima sinyal itu mematuhinya, sedangkan pada gerak isyarat (gesture) penerima dan pemberi gerak-isyarat mempunyai relasi yang sejajar. Selain itu, dalam gerak-isyarat, yang difokuskan adalah komunikasi timbal balik atau komunikasi dua arah (two-way communication).

Gerak-isyarat lebih difokuskan pada cara penyampaiannya daripada hubungan antara yang mewakili dengan yang diwakilinya. Jika gerak-isyarat ditinjau dari segi hubungan yang diwakili dan yang mewakilinya (petanda dan penanda), maka dapat dikatakan bahwa gerak-isyarat itu adalah termasuk simbol, sinyal dan tanda. Biasanya, gerak-isyarat yang dihasilkan oleh manusia bisa termasuk tanda dan bisa juga termasuk simbol. Dalam hubungan ini, Barber ${ }^{12}$ mengatakan yang demikian berlaku pada gerak-isyarat.

Berbeda dengan tanda-tanda lain, gejala (symptom) merupakan tanda yang muncul dengan sendirinya secara ilmiah di tengah-tengah suatu situasi. Dia cenderung merupakan suatu perubahan atau penyimpangan dari kebiasaan yang patut diperhatikan. Selain itu, dia merupakan suatu peristiwa yang mendahului dan memberitahukan peristiwa lain yang mungkin akan terjadi. Kita ambil sebuah contoh. Ketika seseorang deman selama beberapa hari, dokter mengatakan, "Perlu dirawat secepat mungkin. Ini gejala tipus." Pada saat si dokter mengucapkan kalimat itu, penyakit tipus yang mungkin terjadi itu belum terjadi, tetapi gejalanya lebih dahulu muncul.

Pemakaian gejala biasanya terbatas karena hanya golongan orang tertentu yang dapat menjelaskan artinya. Gejala tidak mengungkapkan yang sudah ada, melainkan yang mungkin ada. Akan tetapi, gejala bisa menjadi sinyal apabila dikonversikan. Dengan demikin, dapat dikatakan bahwa gejala (symptom) adalah suatu tanda yang tidak sengaja, yang dihasilkan tanpa maksud, dan yang alamiah untuk menunjukkan atau mengungkapkan bahwa sesuatu akan terjadi.

Istilah berikutnya adalah gambar (ikon). Gambar ini merupakan tanda yang paling mudah dimengerti karena kemiripannya dengan yang digambarkannya. Gambar yang dimaksudkan dalam hal ini adalah segala tiruan barang, benda atau alam, baik berupa kertas, karton, batu maupun logan; baik berupa coretan, potret, lukisan maupun patung yang mirip atau menyerupai objek tiruannya.

Tidak tertutup kemungkinan bahwa gambar (ikon) itu bisa juga diinterpretasi menjadi sebuah simbol. Bila ditinjau dari segi kemiripan bentuknya maka bisa digolongkan pada gambar atau ikon, tetapi bila ditinjau dari isi yang dikandungnya maka dapat

${ }^{12}$ C.L. Barber, Op. Cit., hal. 18. 
digolongkan pada simbol. Patung Sisingamangaraja XII yang terdapat di Medan, misalnya, menunjukkan kemiripan pada wajahnya maka patung itu dapat diklasifikasikan pada gambar (ikon). Akan tetapi, patung itu sendiri dapat menyimbolkan kepahlawanan. Lebih jauh lagi bahwa patung itu dapat menunjukkan, (sebagai tanda (sign) dan sinyal (signal) menurut pengertian diatas), salah seorang pejuang nasional Indonesia yang berasal dari Tapanuli.

Istilah yang terakhir adalah kode (code). Kode ini sengaja dijelaskan terakhir karena berhubungan dengan keseluruhan tanda sebelumnya. Perbedaannya terdapat pada sistem yang dimilikinya. Dengan demikian, kode adalah sesuatu yang bersistem, baik berupa simbol, sinyal (signal) maupun gerak-isyarat yang dapat mewakili pikiran, perasaan, ide, benda, dan tindakan yang disepakati untuk maksud tertentu. Misalnya, polisi yang beroperasi untuk melacak buronan menggunakan simbol bahasa khusus dalam komunikasinya. Simbol bahasa itu mempunyai sistem tertentu dan digunakan untuk maksud tertentu. Simbol semacam itu termasuk kode.

Pengklasifikasian tanda secara sistematis dilakukan oleh Charles Sanders Peirce, seorang filosof pragmatis dan sekaligus ahli logika Amerika. Tanda diklasifikasikan ke dalam tiga jenis berdasarkan relasi antara tanda sebagai representan dengan denotatumnya yaitu: ${ }^{13}$

1) Simbol, yaitu tanda yang dapat melambangkan atau mewakili sesuatu (ide, pikiran, perasaan, benda, dan tindakan) secara arbitrer dan konvensional. Misalnya, warna merah dan putih dalam bendera kebangsaan Indonesia masing-masing melambangkan keberanian dan kesucian.

2) Indeks, yaitu tanda yang dapat menunjukkan sesuatu (ide, pikiran, perasaan, benda, dan tindakan) secara kausal atau faktual. Misalnya, asap menunjukkan adanya api.

3) Ikon, yaitu tanda yang dapat menggambarkan sesuatu (ide, pikiran, perasaan, benda, dan tindakan) berdasarkan persamaan atau perbandingan. Misalnya, potret menggambarkan orangnya.

Relasi antara tanda sebagai representan dengan denotatum di atas didasarkan pada sifat hubungan itu sendiri. Apabila hubungan antara tanda atau representan dengan denotatum atau objek melambangkan atau mewakili secara arbitrer dan konvensional, tanda itu disebut simbol, apabila menunjukkan secara kausal dan faktual, tanda itu disebut indeks; dan apabila menggambarkan berdasarkan persamaan atau perbandingan, tanda itu disebut ikon.

${ }^{13}$ Charles Sanders Peirce, "Logic and Semiotics The Theory Of Signs", p.102, The Fhilosophy Of Peirce; Selected Writing, Ed.J.Buchler, (London: Routledge and Kegan Paul, 1956), p. 99-275, lihat juga Robert Sibarani, "Hakekat Bahasa", (Bandung: PT Aditya Bakti, 1992), hal. 15. 
Berdasarkan pengklasifikasian tersebut maka tanda (sign), yang selalu dikontraskan dengan simbol sebagaimana diuraikan di atas, sinyal (signal) dan gejala (symptom) dapat diklasifikasikan ke dalam indeks, sedangkan gerak-isyarat (gesture) dan kode (code) dapat diklasifikasikan ke dalam simbol, indeks atau ikon bergantung pada sifat hubungan antara tanda itu dengan denotatumnya.

Semua tanda di atas termasuk dalam bidang semiotika atau semiologi yaitu ilmu yang mempelajari seluk-beluk tanda (simbol, indek, dan ikon). Tanda mampu melambangkan, menunjukkan, dan menggambarkan sesuatu kepada penafsir (interpreter) atau penerima tanda. Tanda mampu berfungsi sebagai media perantara untuk menyampaikan pesan berupa ide, pikiran, perasaan, benda atau tindakan dari pemberi tanda kepada penerima tanda. Proses penyampaian itu disebut tindak komunikasi.

Dengan kata lain, tanda (simbol, indeks, dan ikon) adalah media komunikasi (mediums of communication) yang berpijak dalam bidang semiotika. Untuk lebih jelasnya dapat dilihat pada ilustrasi berikut ini. Lingkaran pertama (paling dalam) menyatakan isi atau kandungan tanda, lingkaran kedua menunjukkan bahwa isi tanda itu dapat ditransformasikan ke dalam tiga jenis tanda, lingkaran ketiga menunjukkan bahwa tanda-tanda itu dapat juga diklasifikasikan ke dalam jenis tanda pada lingkaran kedua, dan lingkaran keempat menunjukkan bahwa tanda yang terdiri atas simbol, indeks, dan ikon merupakan bidang semiotik dan dapat digunakan dalam komunikasi.

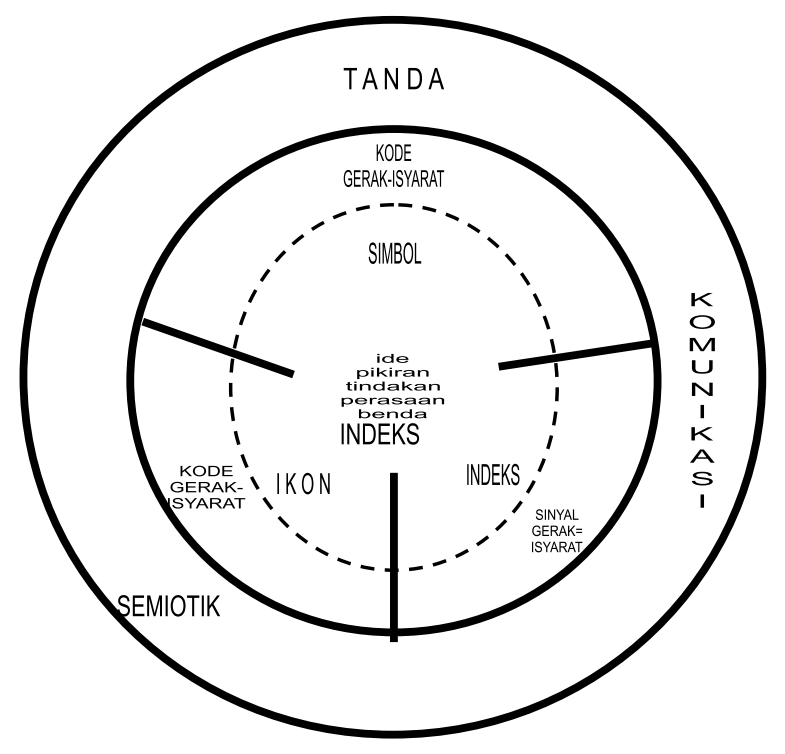

\section{b. Hubungan Manusia dengan Simbol}

Manusia senantiasa bergelut dengan simbol atau lambang. Melalui simbol, manusia memandang, memahami, dan menghayati 
alam dan kehidupannya. Simbol itu sendiri sebenarnya merupakan kenyataan hidup, baik kenyataan lahiriah maupun kenyataan batiniah yang disimbolkan, karena di dalam simbol terkandung ide, pikiran, perasaan, dan tindakan manusia. Dengan demikian, simbol merupakan realitas lahir-batin yang merepresentasikannya misteri kehidupan manusia dan lewat interprestasi, simbol dapat menghadirkan dan menunjukkan eksistensi manusia.

Simbol juga merupakan hasil karya yang diciptakan manusia untuk dipergunakan sebagai wadah atau alat mentransfer ide, pikiran, perasaan, tindakan dan benda di dalam tindakan komunikasi. Komunikasi itu dapat berlangsung antara seseorang dengan orang lain dan dapat juga dengan dirinya secara internal.

Dengan demikian, simbol merupakan alat komunikasi yang diciptakan manusia, baik untuk dirinya sendiri maupun untuk orang lain. Sehubungan dengan pernyataan ini, Kenneth Burke lewat Gordon ${ }^{14}$ menggambarkan manusia sebagai berikut: manusia adalah makhluk pemakai simbol (pembuat simbol, penyalah guna simbol), penemu hal-hal yang negatif (atau dimoralisasikan oleh hal-hal yang negatif), terpisah dari kondisi alamiahnya disebabkan oleh alat yang dia ciptakan sendiri, didorong oleh semangat kehierarkian (atau digerakkan oleh rasa patuh pada peraturan), dan curang demi kesempurnaan.

Manusia dalam setiap lingkup budaya memang telah terikat atau bergantung pada dunia simbolisme sejak beratus ribu tahun yang lalu, namun tidak dapat disangkal bahwa dunia simbolis sering diterima begitu saja. Simbol itu dapat berperan sebagai perluasan dunia pengalaman manusia secara langsung. Melalui simbol, manusia mengabstraksikan dan mengangkat dunia empiris untuk selanjutnya diverifikasi oleh dunia rasional.

Bahkan George Herbert Mead ${ }^{15}$ berpandangan bahwa pikiran atau kesadaran muncul dari proses penggunaan simbol secara tidak kelihatan (covert) khususnya simbol-simbol bahasa. Dengan kata lain, pikiran adalah proses penggunaan simbol secara internal atau secara tidak kelihatan. Hubungan antara komunikasi dengan kesadaran subjektif sedemikian dekatnya sehingga proses berpikir subjektif atau refleksi dapat dipandang sebagai sisi yang tidak kelihatan dari komunikasi.

Manusia memiliki kecenderungan memikirkan tindakantindakan yang potensial lebih dahulu dari pelaksanaannya dan menilainya menurut konsekuensi-konsekuensi yang dibayangkan

\footnotetext{
${ }^{14}$ George N. Gordon, "The Languages Communication”, (New York: Hasting House Publishers, 1969), hal.. 51.

${ }^{15}$ George Herbet Mead, dalam Hockett, Charles F., “A Course In Modern Linguistis”, (New York: The Macmillan Company, 1958), hal. 89.
} 
terlebih dahulu termasuk reaksi-reaksi yang mungkin muncul dari orang lain. Hal ini menuntut manusia untuk menjadi objek bagi dirinya sendiri yang kesadaran tentang diri atau refleksi demikian dinyatakan oleh Martindle, ${ }^{16}$ 1960; Johnson. ${ }^{17}$

Sudah disebutkan di atas bahwa simbol adalah bagian tanda yang merupakan objek kajian semiotika. Secara psikologis, pengalaman kehidupan manusia terdapat dalam sekitar tanda-tanda itu sebagaimana dikatakan Zoest, ${ }^{18}$ bahwa hipotesis akhir semiotika psikologi adalah bahwa manusia berhakikat semiotik. Manusia akan memberitahukan sesuatu yaitu sesuatu yang berarti. Ada dorongan semiotik dalam dirinya, yang mengakibatkan setiap momen yang ada dalam dirinya dan khususnya dalam kehadiran yang lain melalui cara tanda-tanda yang dinyatakan, dan dengan cara yang demikian, dia memberitahukan siapa dan apa dia serta apa yang dia kehendaki. Kemampuannya dalam melakukan itu adalah karena dia mengatur alat-alat itu (tanda-tanda) untuk digunakan. Hal itu merupakan kompetensi semiotika.

Komunikasi melibatkan dua orang atau dua kelompok manusia yang masing-masing disebut pemancar (addresser) dan penerima (addressee), tetapi di balik pengertian itu terdapat kesepakatan bahwa kedua belah pihak hanya bisa berkomunikasi apabila simbol yang digunakan sudah merupakan milik kelompok sosial yang sama. Dengan kata lain simbol yang digunakan pemancar dan penerima itu harus milik bersama kelompok sosial itu. Misalnya, Bambang yang menggunakan simbol bahasa milik kelompok Jawa tidak akan bisa berkomunikasi dengan Maria yang menggunakan simbol bahasa milik kelompok sosial Flores, kecuali kalau sudah terjadi akulturasi simbolis. Jadi, dalam hal ini, simbol sebagai ciptaan manusia adalah milik kelompok sosial yang merupakan hasil proses sosial dan sekaligus merupakan syarat interaksi sosial. Bukanlah karena bahasa baik verbal maupun melalui gambar maka manusia dapat bersatu dan berinteraksi? Tampaknya memang aneh karena simbol sebagai milik kelompok sosial, juga sekaligus merupakan syarat utama terjadinya kelompok sosial. Milik menyatu dengan diri pemiliknya sehingga tidak terpisahkan.

Syarat yang disebut di atas dipandang Gordon ${ }^{19}$ dari sisi yang lebih dalam lagi dengan berkata bahwa simbolisme bukan hanya

\footnotetext{
${ }^{16}$ Don Martindle, "The Nature and Types of Sociological Theory”, (Massachusetts: The Rivers Press, 1960).

17 Johnson, Doyle Paul, "Teori Sosiologi: Klasik dan Modern", DiIndonesiakan oleh Robert M.Z. Lawang, (Jakarta: PT. Gramedia, 1986), hal. 17.

${ }^{18}$ Aart van Zoest, "Semiotiek", (Belgia: Basisboeken/Ambo/Baarn, 1978), hal. 131.

${ }^{19}$ George N. Gordon, Op. Cit., hal. 68.
} 
hasil proses sosial, melainkan juga merupakan suatu syarat pengalaman sosial, yang lebih memikat dan mengarahkan manusia pada komunikasi, pada seni, pada penulisan sejarah, dan pada gudang besar simbolisme yang tercakup dalam penalaran induktif dan akhirnya pada ilmu-ilmu yang dihasilkannya. Tentu saja, itu merupakan syarat peradaban.

Simbol sebagai ciptaan manusia dalam kelompok sosial juga merupakan hasil budaya. Oleh karena itu, disamping simbol berfungsi sebagai alat komunikasi, syarat interaksi sosial, kenyataan hidup, dan sebagainya, dia juga merupakan unsur kebudayaan yang dibanggakan manusia. Misalnya, Candi Borobudur merupakan simbol tingginya daya cipta nenek moyang bangsa Indonesia. Simbol fisik itu mampu mengungkapkan bahwa nenek moyang bangsa Indonesia sudah lama memiliki kreativitas teknik dan seni. Selain itu, Candi Borobudur itu sendiri merupakan salah satu unsur kebudayaan yang didalamnya tercakup atau tergambar sistem pengetahuan, teknologi, dan seni manusia penciptanya

Pertanyaan yang timbul adalah apakah hubungan simbol dengan kehidupan manusia? simbol atau lambang merupakan hasil karya manusia yang diciptakan untuk dipergunakan sebagai wadah atau alat mempresentasikan ide pikiran, perasaan, tindakan, benda didalam tindak komunikasi.

Komunikasi itu dapat berlangsung antara seorang dengan orang lain dan dapat juga dengan dirinya secara internal maupun eksternal. Dalam tataran yang demikian itu simbol atau lambang merupakan alat komunikasi yang diciptakan manusia baik untuk dirinya sendiri maupun untuk orang lain dan melalui simbol atau lambang manusia memandang, memahami dan menghayati alam kehidupannya.

Simbol atau lambang sebenarnya merupakan tindakan batiniah, yang disimbolkan karena di dalam simbol itu terkandung ide, pikiran, perasaan, dan tindakan manusia. Dalam hal yang demikian itu, simbol merupakan realitas lahir batin yang mempresentasikan misteri kehidupan manusia dan lewat interprestasi, simbol atau lambang dapat menghadirkan dan menunjukkan eksistensi manusia.

Jika pengertian diatas dihubungkan dengan masyarakat nasional yang disebut negara atau bangsa, maka pada hakekatnya negara atau bangsa itu juga wadah berhimpunnya manusia-manusia yang memiliki pembawaan kodrati sifat dinamis. ${ }^{20}$ Lambang negara yang berbentuk burung Rajawali Garuda Pancasila yang gambar resminya terlampir dalam Peraturan Pemerintah Nomor 66 Tahun 1951 tentang Lambang Negara sekarang menjadi lampiran resmi Undang-Undang Nomor 24 Tahun 2009 Tentang, Bendera, Bahasa dan Lambang Negara Serta Lagu Kebangsaan kiranya dapat

${ }^{20}$ Dimyati Hartono, Dinamisasi Stabilitas Nasional, Suara Pembaharuan, Kamis, 30 Mei 1996, hal. 2. 
dikatakan sebagai lambang yang dibuat oleh bangsa Indonesia yang bersifat dinamis, artinya melalui lambang itu bangsa Indonesia mempresentasikan, memandang, memahami dan menghayati totalitas kehidupan berbangsa, bernegara dan bermasyarakat atau dengan perkataan lain menjadikan simbol atau lambang negara itu sebagai wadah atau alat yang mampu melingkupi dan mempresentasikan, ide, perasaan, pikiran dan tindakan bangsa Indonesia dalam kehidupan berbangsa, bernegara dan bermasyarakat sesuai jatidiri bangsanya.

Pembuatannya melalui proses yang dirancang secara konvensional dan alegoris berbentuk gambar (ikon) yang berfungsi sebagai lambang negara resmi negara Republik Indonesia yang digali berdasarkan simbol-simbol yang hidup dalam peradaban bangsa Indonesia.

Dirancang secara konvensional, artinya adanya suatu kesepakatan atau persetujuan dalam proses perancangannya oleh masyarakat dalam hal ini bangsa Indonesia melalui institusi (kelembagaan) dalam hal ini Presiden dan DPR. Persetujuan tersebut kemudian dituangkan dalam peraturan perundang-undangan dalam hal ini Peraturan Pemerintah. Disebut alegoris, karena perancangannya yang disengaja sebagai hasil pemufakatan bersama dari perancang dan permufakatan dalam rapat Panitia Lambang Negara serta didalam rapat-rapat Dewan Menteri dibawah Konstitusi RIS 1950. Hal ini berarti lambang negara tersebut dibuat atas dasar perpaduan yang dapat dipertanggungjawabkan secara rasional.

Pertanyaan yang perlu diajukan adalah jika benar lambang negara Indonesia adalah merupakan representasi yang mewakili ide, tindakan bangsa Indonesia dan dirancang atau dibuat atas dasar perpaduan yang dapat dipertangungjawabkan secara rasional, mengapa sejarah perancangan tidak terpaparkan atau tidak muncul secara akademis dalam sejarah hukum Indonesia.

Patut disadari, bahwa secara historis sejak berdirinya negara Republik Indonesia 17 Agustus 1945 sampai dengan 10 Februari 1950, negara Indonesia belum memiliki lambang negara, karena lambang negara sebagaimana bentuk gambar lambangnya seperti sekarang ini baru ditetapkan pada tanggal 11 Februari 1950 yang merupakan penjabaran dari Pasal 3 ayat (3) Konstitusi RIS 1949: Pemerintah Menetapkan Materai dan Lambang Negara. Kemudian tata cara penggunaan Lambang Negara baru diatur Peraturan Pemerintah Nomor 43 tahun 1958 dan Peraturan Pemerintah Nomor 66 tahun 1951 atas imperatif Pasal 3 ayat (3) UUDS 1950. Kemudian kembali ke UUD 1945, maka berdasarkan Pasal II aturan beralihan, tetap diberlakukan kedua Peraturan Pemerintah tersebut, sampai dengan pada amandemen kedua UUD 1945 kemudian diatur pada pasal 36A: Lambang Negara ialah Garuda Pancasila dengan semboyan Bhinneka Tunggal Ika. 
Menurut risalah sidang MPR tahun 2000, bahwa masuknya ketentuan mengenai lambang negara kedalam Undang-Undang Dasar Negara Republik Indonesia 1945 yang melengkapi pengaturan mengenai bendera negara dan bahasa negara yang telah ada sebelumnya merupakan ikhtiar untuk memperkukuh kedudukan dan atribut kenegaraan ditengah kehidupan global dan hubungan internasional yang terus berubah. Dengan kata lain, kendati pun atribut itu tampaknya simbolis, hal tersebut tetap penting, karena menunjukkan identitas dan kedaulatan suatu negara dalam pergaulan internasional. Atribut kenegaraan itu menjadi simbol pemersatu seluruh bangsa Indonesia di tengah perubahan dunia yang tidak jarang berpotensi mengancam keutuhan dan kebersamaan sebuah negara dan bangsa tak terkecuali bangsa dan negara Indonesia. ${ }^{21}$

\section{c. Konsep Semiotika Hukum}

Pertanyaan yang perlu diajukan adalah apakah pengertian semiotika? terminologi semiotika atau semiologi merupakan terminologi yang berasal dari kata Yunani, "semeion"/ Tanda"/Simbol, karena secara sederhana semiotika sering disebut sebagai "study of sign" (suatu pengkajian tanda-tanda), yang oleh Kris Budiman dan Scholes dijelaskan sebagai studi atas kode-kode atau simbol-simbol, yaitu sistem apapun yang memungkinkan seseorang memandang entitas-entitas tertentu sebagai tanda-tanda atau sebagai sesuatu yang bermakna. ${ }^{22}$

Pandangan lain seperti Saussure menyebutnya sebagai ilmu umum tentang tanda, suatu ilmu yang mengkaji kehidupan tandatanda didalam masyarakat (a science that studies the life of sign within society $)^{23}$ pandangan lain adalah menurut Rahayu Surtiati Hidayat, menurutnya semiotika adalah teori dan analisis berbagai tanda (sign)/simbol (simbolic) dan pemaknaan (signification) ${ }^{24}$

Pertanyaan berikutnya adalah apa yang menjadi studi utama Semiotika? Dengan mendasarkan pada pandangan dari Charles Moris, yaitu seorang filsuf yang menaruh perhatian atas ilmu

21 MPR RI, Panduan Pemasyarakatan Undang-Undang Dasar Negara Republik Indonesia Tahun 1945 sesuai dengan Urutan Bab, Pasal, dan Ayat, (Jakarta: Sekretariat Jenderal MPR.RI, 2007). 3.

${ }^{22}$ Kris Budiman, "Semiotika Visual”, (Yogyakarta: Yayasan Seni Cemeti, 2003), hal.

${ }^{23}$ Ferdinand D. Saussure, "Course in General Linguistic”, (USA: McGraw-Hill, New York University, 1996), hal. 16.

${ }^{24}$ Rahayu Surtiati Hidayat, "Semiotik dan Bidang Ilmu", dalam Semiotika Budaya, yang disunting T. Christomy \& Untung Yuwono, 2004, Pusat Penelitian Kemasyarakatan dan Budaya Direktorat Riset dan Pengabdian Masyarakat Universitas Indonesia, Jakarta, hal. 77. 
tentang-tanda-tanda sebagaimana disitir oleh Kris Budiman menjelaskan bahwa, semiotika pada dasarnya dapat dibedakan dalam tiga cabang penyelidikan (branches of inquery), yakni sintaksis, semantik, dan pragmatik, yang dapat dipaparkan sebagai berikut: ${ }^{25}$

1. Sintaktik atau sintaksis, suatu cabang penyelidikan semiotika yang mengkaji "hubungan formal diantara suatu tanda dengan tanda yang lain", dengan perkataan lain, karena hubunganhubungan formal ini merupakan kaidah-kaidah yang mengendalikan tuturan dan interpretasi.

Pengertian sintaktik kurang lebih adalah semacam metode penafsiran gramatikal (bahasa) dalam Ilmu hukum, yaitu penafsiran yang menekan pada makna teks yang di dalamnya kaidah hukum dinyatakan. Penafsiran dengan cara demikian bertolak dari makna menurut pemakaian bahasa sehari-hari atau makna teknis yuridis yang sudah dilazimkan.

Menurut Vissert Hoft, di negara-negara yang menganut tertib hukum kodifikasi, teks harfiah undang-undang dinilai sangat penting. Namun penafsiran gramatikal saja tidak cukup jika tentang hal yang ditafsirkan itu sudah menjadi perdebatan; ${ }^{26}$

2. Semantik, yaitu cabang penyelidikan semiotika yang mempelajari "hubungan diantara tanda-tanda dengan degsinata atau objek-objek yang diacunya". Bagi Vissert Hoft yang dimaksudkan dengan degsinata adalah makna tanda-tanda sebelum digunakan didalam tuturan tertentu;

3. Pragmatik, suatu cabang penyelidikan semiotika yang mempelajari "hubungan diantara tanda-tanda dengan interpreter atau para pemakainya-pemaknaan tanda-tanda. Pragmatik secara khusus berurusan dengan aspek-aspek komunikasi, khususnya fungsi-fungsi situasional yang melatari tuturan.

Menurut John Fiske, studi semiotika dapat dibagi kedalam bagian sebagai berikut: ${ }^{27}$

1. Tanda/simbol itu sendiri, hal ini terdiri atas studi tentang berbagai tanda/simbol yang berbeda, cara tanda/simbol yang berbeda itu dalam menyampaikan makna, dan cara tanda-tanda itu terkait dengan manusia yang menggunakannya. Tanda/simbol adalah konstruksi manusia dan hanya bisa dipahami dalam artian yang menggunakannya. Menurut penukis

${ }^{25}$ Kris Budiman, Op. Cit., hal. 4-5.

${ }^{26}$ Visser't Hoft, "Penemuan Hukum", judul asli "Rechtsvinding”, diterjemahkan oleh B. Arief Sidharta, (Bandung: Laboraturium Hukum FH Univ, Parahiayangan, 2001), hal. 25.

${ }^{27}$ John Fiske, “Cultural and Communication Studies”, (Yogyakarta: Jalasutra, 2004), hal. 60-61. 
jika dikaitkan dengan lambang negara, misalnya maka simbolsimbol yang ada pada lambang negara itu dapat dipahami dengan pemaknaan yang diberikan oleh negara terhadap makna simbol-simbol yang ada dalam lambang negara.

2. Kode atau sistem yang mengorganisasikan tanda/simbol, Studi ini mencakup cara berbagai kode dikembangkan guna memenuhi kebutuhan suatu masyarakat atau budaya atau mengekploitasi saluran komunikasi yang tersedia untuk mentransmisikannya.

3. Kebudayaan atau tempat kode dan tanda/simbol bekerja. Ini pada gilirannya bergantung pada penggunaan kode-kode dan tanda-tanda/simbol-simbol itu untuk keberadaan dan bentuknya sendiri.

Untuk memahami studi semiotika lebih mendalam, maka Yasraf Amir Pialang menjelaskan tentang beberapa elemen penting dari semiotika yang meliputi beberapa hal sebagai berikut: ${ }^{28}$

1. Komponen tanda/simbol: Apabila praktik sosial, politik, ekonomi, budaya, dan seni sebagai fenomena bahasa, maka ia dapat pula dipandang sebagai tanda/simbol. Hal ini dimungkinkan karena luasnya pengertian tanda/simbol. Meskipun demikian, didalam masyarakat informasi saat ini terjadi perubahan mendasar bagaimana "tanda/simbol" dipandang dan digunakan. Ini disebabkan karena arus pertukaran tanda/simbol tidak lagi berpusar didalam suatu komunitas tertutup, akan tetapi melibatkan persinggungan di antara berbagai komunitas, kebudayaan dan ideologi.

2. Aksis Tanda: Analisis tanda berdasarkan sistem atau kombinasi yang lebih besar melibatkan apa yang disebut aturan pengkombinasian yang terdiri dari dua aksis, yaitu aksis paradigmatik, yaitu perbendaharaan tanda atau kata serta askis sintakgmatik, yaitu cara pemilihan dan pengkombinasian tandatanda/simbol/simbol, berdasarkan aturan (rule) atau kode tertentu, sehingga dapat menghasilkan sebuah ekspresi yang bermakna.

3. Tingkatan Tanda: Barthes mengembangkan dua tingkatan penandaan, yang memungkinkan untuk dihasilkan makna yang juga bertingkat-tingkat. "Denotasi", yaitu pertandaan yang menjelaskan hubungan penanda dan petanda, atau antara tanda dan rujukan pada realitas yang menghasilkan makna yang eksplisit, langsung dan pasti. Konotasi, tingkat pertandaan yang menjelaskan hubungan antara penanda dan petanda, yang

${ }^{28}$ Yasraf Amir Piliang, "Hipersemiotika; Tafsir Cultural Studies Atas Matinya Makna", (Yogyakarta: Jalasutra, 2003), hal. 257. 
didalamnya beroperasi makna yang tidak ekspilisit, tidak langsung dan tidak pasti artinya;

4. Relasi antar Tanda: Selain kombinasi tanda analisis semiotika juga berupa berupaya untuk mengungkapkan interaksi diantara tanda-tand/simbol-simbol. Meskipun bentuk interaksi antar tanda-tanda/simbol-simbol itu sangat terbuka, akan tetapi ada dua interaksi utama yang dikenal yaitu "metafora", sebuah model interaksi tanda/simbol, yang didalamnya sebuah tanda/simbol dari sebuah sistem digunakan untuk menjelaskan makna untuk sebuah sistem yang lainnya, misalnya di dalam lambang negara Indonesia ada perisai besar dan perisai kecil yang kesemuanya dibagi menjadi lima ruang yang di dalamnya ada simbol-simbol yang mensimbolisasikan Pancasila, tetapi struktur letaknya dan cara membacanya dapat digunakan untuk menjelaskan sebuah sistem yang lainnya, misalnya sistem norma hukum dan keduanya ada bentuk interaksi "metafora", yaitu antara cita hukum Pancasila dan sistem norma hukum yang seharusnya mengacu pada metafora pembacaan cita hukum dalam dalam lambang negara.

Berdasarkan pengertian semiotika dan obyek studi semiotika serta elemen penting dari semiotika di atas, maka menurut penulis dapat ditarik pengertian semiotika, bahwa ada dua pengertian: Pertama, ilmu yang mempelajari/mengkaji tentang tandatanda/simbol-simbol beserta pemaknaan yang terdapat didalam simbol-simbol itu sendiri. Kedua, sebuah teori dan analisis berbagai tanda (sign)/simbol (simbolic) dan pemaknaan (signification) di dalamnya serta tata cara penggunaannya dalam kehidupan manusia.

Berkaitan dengan pengertian semiotika di atas, maka menurut penulis pengertian kedua lebih representatif untuk menjelaskan semiotika hukum terhadap analisis lambang negara, karena salah satu pengertian hukum, yaitu hukum sebagai simbol yang di dalamnya ada nilai-nilai sesuatu yang dapat melambangkan dan mewakili ide, pikiran, perasaan, dan tindakan secara arbriter, konvensional, representatif, interpretatif baik makna yang batiniah (inear) maupun yang lahiriah (outer) yang dilambangkan atau diwakili simbol.

\section{d. Analisis Semiotika Hukum Terhadap Lambang Negara Republik Indonesia}

Jika kita menganalisis sejarah hukum lambang negara Republik Indonesia, maka secara semiotika hukum ditemukan rekonstruksi hasil studi hukum Tata Negara dengan pendekatan analisis sejarah hukum (historis yuridis) sebagai berikut:

1. Lambang Negara baru dirancang oleh Sultan Hamid II adalah di masa RIS,1950 dan ditetapkan oleh Parlemen dan Pemerintah 
RIS pada tanggal 11 Februari 1950 dan diperkenalkan ke publik tanggal 15 Februari 1950. Bentuk gambarnya secara semiotika adalah figur Elang Rajawali dan disingkat Rajawali Garuda Pancasila. Lambang Negara ini semula dimaksudkan sebagai lambang Negara RIS (Republik Indonesia Serikat), 1950.

2. Terjadi pergeseran secara semiotika terhadap gambar lambang Negara, yaitu pada tahap pertama rancangan yang dibuat oleh Sultan Hamid II adalah menggunakan figur burung garuda hal ini dibuktikan dari sketas awal sampai dengan akhir (8 Februari 1950) dan pada perancangan tahap kedua kemudian disempurnakan secara terus menerus oleh Sultan Hamid II atas masukan Presiden Soekarno. Pada tanggal 11 Februari 1950 lambang negara mengambil figur Burung Elang Rajawali, sebagaimana dinyatakan Presiden Soekarno dalam pidato tentang Lambang Negara 22 Juli 1958 atau selaras dengan Penjelasan Pasal 4 jo pasal 6 PP No 66 Tahun 1951 atau penjelasan Pasal 48 UU No 24 Tahun 2009, dan selaras pula dengan transkrip Sultan Hamid II, 15 April 1967.

3. Lambang Negara Republik Indonesia baru menjadi bagian dari UUD Negara RI 1945 setelah amandemen kedua, tahun 2000 berdasarkan rekomendasi Seminar Nasional Lambang Negara di Pontianak 2-3 Juni 2000 yang kemudian menjadi materi muatan konstitusi - UUD Negara RI 1945 pasal 36 A dan berdasarkan pasal $36 \mathrm{C}$ dijabarkan lebih lanjut dalam UU Nomor 24 tahun 2009.

4. Secara analisis semiotika, struktur lambang Negara terdiri dari tiga konsep Figur Lambang identitas Negara yaitu Elang Rajawali-dan Dasar Negara Pancasila dalam perisai Pancasila, dan jati diri bangsa Indonesia, pada seloka Bhinneka Tunggal Ika. Khususnya pada perisai Pancasila merupakan perpaduan ide dari usulan anggota Panitia Lambang Negara RIS, simbol Sila Kesatu sumbangan ide dari Moh Natsir, simbol Sila Kedua ide dari Sultan Hamid II dan sketsa gambar perisai dan garis khatulistiwa adalah usulan Sultan Hamid II, simbol Sila Ketiga sumbangan ide dari Purbatjaraka, simbol Sila Keempat sumbangan ide dari Mohammad Yamin, simbol Sila Kelima sumbangan ide dari Ki Hajar Dewantoro. Walaupun demikian sketsa awal hingga perancangan gambar lambang negara sampai ditetapkan pemerintah RIS 11 Februari 1950 adalah dibuat oleh Sultan Hamid II seperti dinyatakan secara tegas oleh Mohammad Hatta, sedangkan sang pelukis gambarnya adalah Dullah berdasarkan penyempurnaan yang terus-menerus oleh Presiden Soekarno dan Mohammad Hatta kepada Sultan Hamid II.

5. Pembacaan Pancasila berdasarkan analisis semiotika hukum pada perisai Pancasila dalam lambang Negara menggunakan 
konsep "berthawaf" atau Gilir balik berlawanan dengan arah jarum jam dan di balik konsep itu tersirat dan tersurat pesan filosofis bagi bangsa Indonesia. Pembacaan Pancasila berdasarkan Perisai Pancasila seharusnya menjadi model dalam memahami kehidupan bernegara, berbangsa dan bermasyarakat dalam negara hukum yang bersendikan demokrasi dan berdasarkan teokrasi.

6. Makna Bhinneka Tunggal Ika sebenarnya merupakan representasi dari perpaduan dua paham kenegaraan (federal dan unitaris), oleh karena itu pembacaan Bhinneka Tunggal Ika seharusnya dipahami dan dibaca sebagai keragaman dalam persatuan dan persatuan dalam keragaman atau yang berbhineka satu itu dan yang satu itu berbhineka, itulah bangsa Indonesia, tetapi saat ini dibaca "berbeda-beda tapi satu jua" sehingga keragaman daerah sebagai suatu manesfestasi otonomi daerah belum terwujudkan dan selaras dengan prinsip bhinneka Tunggal Ika.

7. Ada manipulasi sejarah hukum lambang negara dalam masa Orde Baru, bahwa yang merancang lambang negara dinyatakan adalah Mr. Mohammad Yamin, sedangkan Mohammad Hatta, 1978 menyatakan secara tegas, bahwa yang membuat lambang Negara adalah Sultan Hamid II anak bangsa dari Pontianak Kalimantan Barat dalam kedudukan sebagai Menteri Negara Zonder Forto Folio,1950. Kemudian gambarnya ditetapkan parlemen RIS, tanggal 11 Februari 1950. Dalam Kedudukan menteri negara tersebut tidak ada tugas lain yang diperintahkan Presiden Soekarno kepada Sultan Hamid II, yaitu membuat rencana atau merancang Lambang Negara dan menyiapkan Gedung Parlemen. Dimasa Reformasi ada manipulasi atau rekayasa Gambar Lambang Negara yang menjadi lampiran resmi Undang-Undang Nomor 24 tahun 2009 yang berbeda dengan Lampiran Resmi Peraturan Pemerintah Nomor 66 tahun 1951 sebagaimana gambar rancangan terakhir yang diperbaiki seperlunya oleh Sultan Hamid II, sebagaimana dokumen aslinya terdapat di Yayasan Mas Agung yang telah diserahkan oleh Sultan Hamid II 18 Juli 1974 untuk diselamatkan. Selain itu dalam Undang-Undang Nomor 24 tahun 2009 tentang Bendera, Bahasa dan Lambang Negara serta Lagu Kebangsaan ada diskriminasi hukum, karena tidak menyebutkan nama perancang lambang negara (Pasal 46), sebagaimana pasal yang mengatur lagu kebangsaan.(Pasal 58).

8. Untuk pembuktian lambang negara oleh Sultan Hamid II berikut ini distruktur berdasarkan analisis Semiotika Hukum dengan mengacu pada dokumen sejaman, yaitu tahap pertama menggunakan Figur Burung Garuda yang ada pada peradaban bangsa Indonesia dan Tahap Kedua. Perancangan tahap kedua 
adalah merupakan perpaduan dengan peradaban dunia yaitu menggunakan figur Elang Rajawali, sehingga Sultan Hamid II dalam transkrip menamakan lambang negara tersebut ialah RAJAWALI GARUDA PANCASILA atau Soekarno menyebutnya Elang Rajawali - garuda atau secara historis yuridis Teks Hukum (Historis Yuridis) berdasarkan teks hukum Peraturan Pemerintah No 66 tahun 1951 tentang Lambang Negara menyatakan:

Lukisan Garuda diambil dari benda Peradaban Indonesia seperti hidup dalam Mityologi, symbologi dan Kesusasteraan Indonesia dan seperti pula tergambar pada beberapa candi sejak abad ke 6 sampai abad ke 16. (Penjelasan Pasal 1)

Burung Garuda dari mytologi menurut perasaan Indonesia berdekatan dengan burung Elang Rajawali. Burung itu dilukiskan di candi Dieng, Prambanan dan Penataran. Ada kalanya dengan memakai lukis berupa manusia dengan berparuh burung dan bersayap (Dien): dicandi Prambanan dan di candi Jawa Timur seperti berparuh panjang berambut raksasa dan bercakar. Lihatlah lukisan garuda dicandi mendut, Prambanan dan candi-candi Sukuh. Kedal di Jawa Timur. Umumnya maka garuda dikenal baik oleh arkeologi, kesusasteraan dan mitologi Indonesia. Lencana Garuda pernah dipakai oleh Prabu Air Langga pada abad kesebelas dengan bernama Garudamukha. Menurut patung Belahan beliau dilukiskan dengan mengendarai seekor garuda.

Teks hukum (yuridis Formal) Penjelasan Pasal 46 UndangUndang Nomor 24 tahun 2009 tentang Bendera, Bahasa, dan Lambang Negara Serta Lagu Kebangsaan dalam Penjelasan Pasal 46 menyatakan:

Yang dimaksud dengan "Garuda Pancasila" adalah Lambang berupa burung garuda yang sudah dikenal melalui mitologi kuno, yaitu burung yang menyerupai Burung Elang Rajawali.

Pidato Presiden Soekarno pada pidato kenegaraan 22 Juli 1958 menyatakan secara tegas:

Saudara-saudara, Lihatlah Lambang Negara kita dibelakang ini alangkah megahnya, alangkah hebat dan cantiknya. Burung Elang Rajawali, garuda yang sayap kanan dan sayap kirinya berelar 17 buah, ekor yang berelar 8 buah, tanggal 17, bulan 8 dan berkalungkan perisai yang diatas perisai itu tergambar Pancasila... 
Kemudian dalam literatur juga ditemukan istilah Burung Elang Rajawali sebagaimana dinyatakan secara tegas Muhammad Yamin dalam bukunya Pembahasan Undang-Undang Dasar 1945, hal 144 yang menyatakan: ${ }^{29}$

Jadi Burung sakti Elang Rajawali sebagai lambang pembangunan dan pemelihara diseluruh bangsa Indonesia.... "Seperti diperhatikan maka latar lambang itu terbagi atas tiga bagian, yaitu lukisan Elang Rajawali, perisai Pancasila dan seloka Empu Tantular.

Burung sakti Elang Rajawali dilukiskan dengan 17 sayap terbang, 8 helai sayap kemudi dan 45 helai buku sayap sisik pada tubuh. Perlambangan ketiga angka itu ialah lukisan cendra sengkala: 17 Agustus 1945, yaitu hari Proklamasi Kemerdekaan Indonesia.

Penelusuran dari literatur akademik yang lain Soediman Kartohadiprojo, juga menyatakan: ${ }^{30}$

Lambang Ngara kita terdiri dari tiga bagian: (1) Candra Sengkala, (2) Perisai Pancasila, (3) Seloka Bhinneka Tunggal Ika. Candra Sengkala ini terdapat dalam "burung sakti Elang Rajawali (cetak tebal dari penulis) yang bulu sayapnya 17 helai jumlahnya, bulu sayap kemudinya 8 helai, sedangkan bulu sayap sisiknya pada batang tubuhnya berjumlah 45 ini melukiskan hari diproklamasikan Republik Indonesia.

Penegasan siapa perancang lambang negara yang bentuk gambar sekarang ini adalah sebagaimana keterangan Mohammad Hatta itu selengkapnya adalah: ${ }^{31}$

..... Patut pula ditambahkan sebagai catatan bahwa lambang dengan tulisan yang mempunyai arti yang demikian mendalam itu, dipadukan menjadi seperti sekarang ini, dengan melalui sayembara waktu RIS dulu dan dilaksanakan oleh Menteri Priono, Banyak gambar yang masuk waktu itu, tetapi yang terbaik akhirnya ada dua buah, satu dari Muhammad Yamin

${ }^{29}$ Muhammad Yamin, Pembahasan Undang-Undang Dasar 1945, (Jakarta: Prapanca, 1967), hal. 144.

${ }^{30}$ Soediman Kartohadiprojo, Pancasila sebagai Pandangan Hidup Bangsa Indonesia, (Jakarta: Gatra Pustaka, 2010), hal. 229.

${ }^{31}$ Muhammad Hatt, Op. Cit., hal. 108. 
dan yang satu lagi dari Sultan Hamid. Yang diterima oleh Pemerintah dan DPR adalah dari Sultan Hamid yakni seperti sekarang ini. Adapun dari Muhammad Yamin ditolak, karena disana ada gambar sinar-sinar matahari dan menampakan sedikit banyak disengaja atau tidak pengaruh Jepang. Saya berpendapat bahwa apa yang ada sekarang itu, seperti uraian saya tadi sudah tepat dan bernilai abadi bagi kehidupan negara dan bangsa Indonesia.

Pada bagian lain buku Bung Hatta Menjawab: ${ }^{32}$

Semboyan Bhinneka' Tunggal Ika adalah ciptaan Bung Karno, setelah kita merdeka, semboyan itu kemudian diperkuat dengan lambang yang dibuat oleh Sultan Abdul Hamid Pontianak dan diresmikan pemakaiannya oleh Kabinet RIS tanggal 11 Februari 1950.

Proposisi Muhammad Hatta tersebut juga dikuatkan oleh Prof. Dr. R Soepomo, dalam bukunya "Undang-Undang Sementara Republik Indonesia", 1954 ketika menjelaskan bagian ke III Lambang dan Bahasa Negara dalam Konstitusi RIS 1949 Pasal $3:^{33}$

\begin{abstract}
Ichtisar Parlemen, 17 Februari 1950 nomor 2 memuat berita negara, bahwa sidang Dewan Menteri R.I.S tanggal 11 Februari 1950 telah mengesahkan Lambang Negara R.I.S yang direncanakan oleh Panitia Lambang Negara menurut bagian III pasal 3 Konstitusi R.I.S. Gambarnya lambang negara tersebut adalah dimuat dalam ichtisar Parlemen tersebut.
\end{abstract}

\title{
II. Penutup
}

\section{Kesimpulan}

Berdasarkan analisis semiotika hukum terhadap hasil temuan analisis sejarah hukum tersebut di atas, maka dapat ditarik kesimpulan sebagai berikut:

1) Secara analisis semiotika hukum, struktur lambang negara terdiri dari tiga konsep yang merupakan satu kesatuan yang

${ }^{32}$ Ibid., hal. 108.

33 R. Soepomo, Undang-Undang Dasar Sementara Republik Indonesia, (Jakarta: Noordhhof-kolff N.V, 1954), hal. 25. 
harmomis tetapi terbedakan dalam pemaknaan semiotika hukum, yakni (1) figur Lambang sebagai identitas negara proklamasi Indonesia, 17 Agustus 1945 yaitu figur burung Elang Elang Rajawali yang menurut perasaan bangsa Indonesia dalam mitologi dan sastra mendekati burung garuda yang disimbolisasi pada jumlah sayap dan ekor Elang Rajawali, (2) Filsafat dasar negara Pancasila yang diwujudkan dalam perisai Pancasila, dan (3) jatidiri bangsa Indonesia diwujudkan pada simbolisasi seloka Bhinneka Tunggal Ika.

2) Simbol-simbol dalam Perisai Pancasila secara semiotika hukum merupakan perpaduan ide dari usulan anggota Panitia Lambang Negara RIS. Simbol Sila Kesatu sumbangan ide dari Moh Natsir, simbol Sila Kedua ide dari Sultan Hamid II dan sketsa gambar perisai dan garis khatulistiwa adalah usulan Sultan Hamid II, simbol Sila Ketiga sumbangan ide dari Purbatjaraka, simbol Sila Keempat sumbangan ide dari Mohammad Yamin, simbol Sila Kelima sumbangan ide dari Ki Hajar Dewantoro. Walaupun demikian sketsa awal hingga perancangan gambar lambang negara sampai ditetapkan pemerintah RIS 11 Februari 1950 dan disahkan Parlemen RIS 17 Februari 1950 dan kemudian Menjadi Lampiran Resmi Peraturan Pemerintah Nomor 66 Tahun 1951 adalah rancangan lambang negara yang dibuat oleh Sultan Hamid II seperti dinyatakan secara tegas oleh Mohammad Hatta 1978, sedangkan sang pelukis gambar rancangan lambang negara Sultan Hamid II adalah Dullah, sebagai pelukis Istana berdasarkan perintah penyempurnaan yang terus menerus dari Presiden Soekarno kepada Sultan Hamid II sebagaimana dibuktikan dengan disposisi/persetujuan Presiden Soekarno kepada Sultan Hamid II 20 Maret 1950.

3) Sultan Hamid II dalam transkrip 15 April 1967 secara semiotika hukum menamakan lambang Negara Republik Indonesia Serikat tersebut dengan nama Rajawali-Garuda Pancasila, Soekarno menamakan Elang Rajawali-Garuda, Peraturan Pemerintah Nomor 66tahun 1951 pada penjelasan pasal 4 menjelaskan "menurut bangsa Indonesia berdekatan dengan burung Elang Rajawali" dan penjelasan pasal 46 UU Nomor 24 tahun 2009 menjelaskan "menyerupai Elang Rajawali", Muhammad Yamin menyebutnya "Burung sakti Elang Rajawali", Soediman Kartohadiprojo menyebutnya "burung sakti Elang Rajawali”.

4) Dimasa Reformasi gambar lambang negara yang menjadi lampiran resmi Undang-Undang Nomor 24 tahun 2009 sebagaimana dinyatakan teks hukum negara pada pasal 50 terdapat "rekayasa" terhadap bentuk gambar lambang negara Republik Indonesia oleh negara, walaupun gambar lambang negara ini secara semiotika struktur bentuknya sama dengan 
bentuk gambar dan skala ukuran pada Lampiran Resmi Peraturan Pemerintah Nomor 66 tahun 1951, tetapi ada "rekayasa" terhadap corak bentuk sayap, gambar padi-kapas simbolisasi dari Sila Kelima dan tipe huruf tulisan Bhinneka Tunggal Ika oleh negara, sehingga menjadi "tidak asli" dengan bentuk gambar rancangan terakhir yang diperbaiki seperlunya oleh Sultan Hamid II berdasarkan disposisi/persetujuan presiden Soekarno 20 Maret 1950 atau "terjadi manipulasi karya cipta seseorang" sebagaimana dokumen aslinya saat ini terdapat di Yayasan Mas Agung yang dititipkan oleh Sultan Hamid II 18 Juli 1974 kepada H.Mas Agung sebagai ketua Yayasan Idayu Jakarta yang merupakan dokumen lampiran Peraturan Pemerintah Nomor 66 tahun 1951 tentang Lambang Negara.

\section{Saran}

Berdasarkan kesimpulan tersebut, disampaikan saran-saran sebagai berikut:

1) Perlunya penegasan oleh institusi negara terhadap penelurusan sejarah hukum lambang negara Republik Indonesia, bahwa perancang Lambang Negara yang berbentuk Elang Rajawali Garuda Pancasila sebagaimana terlampir dalam Peraturan Pemerintah Nomor 66 tahun 1951 tentang Lambang Negara adalah Sultan Hamid II, yaitu dengan cara, pertama pernyataan resmi dari Presiden selaku Kepala Negara melalui Sekretariat Negara, Kedua, merevisi Undang -Undang Nomor 24 tahun 2009 tentang Bendera, Bahasa dan Lambang Negara serta Lagu kebangsaan pada pasal 46 menjadi berbunyi:

(1) Lambang Negara Kesatuan Republik Indonesia ialah berbentuk Lukisan Elang Rajawali yang kepalanya menoleh lurus kesebelah kanan, perisai yang digantung dengan rantai pada leher Elang Rajawali berisi simbolisasi Pancasila, dan semboyan Bhinneka Tunggal Ika ditulis diatas pita yang dicenkram oleh Elang Rajawali.

(2) Lambang Negara sebagaimana dimaksud pada ayat (1) diatas, proses sejarah perancangan awalnya diambil dari ide dalam mitologi bangsa Indonesia, yaitu mitologi burung Garuda sebagaimana dirancang oleh Sultan Hamid II yang kemudian dalam proses penyempurnaan melalui perbandingan dengan peradaban lambang-lambang negara di dunia dinamakan Rajawali Garuda Pancasila atau saat ini disingkat Garuda Pancasila dengan semboyan Bhinneka Tunggal Ika. 
Pada Penjelasannya perlu direkonstruksi teks hukumnya menjadi:

(1) Yang dimaksud dengan Lukisan Elang Rajawali adalah sebagaimana lukisan lambang negara yang telah ditetapkan untuk pertama kali 11 Februari 1950 dan disahkan Parlemen RIS 17 Februari 1950 kemudian disempurnakan secara terus menerus oleh Sultan Hamid II berdasarkan pesan disposisi/persetujuan Presiden Soekarno 20 Maret 1950, sebagaimana bentuk gambarnya seperti sekarang ini, serta kemudian secara konstitusional ditetapkan menjadi lambang negara Kesatuan Republik Indonesia dalam Undang-Undang Dasar Negara 1945 pasal 36 A, yang kemudian dinamakan Garuda Pancasila dengan semboyan Bhinneka Tunggal Ika.

(2) Yang dimaksud Rajawali-Garuda Pancasila adalah bahwa bentuk gambar lukisan yaitu figur Elang Rajawali, sedangkan Garuda adalah ide pada proses sejarah perancangan awalnya yang sudah dikenal melalui mitologi kuno bangsa Indonesia dan dalam bentuk alamiahnya menyerupai elang Rajawali dalam peradaban lambanglambang negara di dunia, sebagaimana dinyatakan oleh Presiden Soekarno dalam pidato kenegaraannya 22 Juli 1958 "Terbang-terbanglah Elang Rajawali.

2) Pencantuman nama Sultan Hamid II secara hukum adalah selaras dengan Peraturan Perundangan-undangan tentang Hak Cipta, yaitu Undang-Undang No 19 Tahun 2002. Pasal 24 undang-undang inimenyebutkan, bahwa: (1) Pencipta atau ahli warisnya berhak menuntut Pemegang Hak Cipta supaya nama Pencipta tetap dicantumkan dalam ciptaannya. (2) Suatu ciptaan tidak boleh diubah walaupun hak ciptanya telah diserahkan kepada pihak lain, kecuali dengan persetujuan Pencipta atau dengan persetujuan ahli warisnya dalam hal Pencipta telah meninggal dunia. (3) Ketentuan sebagaimana dimaksud pada ayat (2) berlaku juga terhadap perubahan judul dan anak judul ciptaan, pencantuman dan perubahan nama atas nama samaran Pencipta. (5) Pencipta tetap berhak mengadakan perubahan pada Ciptaan sesuai dengan kepatutan masyarakat. Pencatuman Nama Pencipta Lambang Negara dimaksudkan agar tidak terjadi diskriminasi hukum dalam Undang-Undang Nomor 24 Tahun 2009 antatra Pasal 46 yang mengatur Lambang Negara dengan Pasal 58 Undang-undang 24 Tahun 2009 yang mengatur Lagu Kebangsaan.

3) Sosialisasi Empat Pilar Kenegaraan yang dicanangkan MPR RI perlu mengapresiasi Pembacaaan Pancasila berdasarkan Perisai Pancasila dalam lambang negara dengan menggunakan model 
konsep Pancasila "berthawaf" sebagai konsep yang selaras dengan sejarah hukum lambang negara dan pembacaan Perisai Pancasila berdasarkan Pasal 48 ayat (2) Undang-Undang Nomor 24 Tahun 2009.

4) Pemahaman terhadap konsep Bhinneka Tunggal Ika bukan dibaca berbeda-beda satu jua, tetapi Bhina Ika, Tunggal Ika, yang beranekaragam itu satu dan yang satu itu beraneka ragam, atau keragaman dalam persatuan dan persatuan dalam keragaman.

5) Disarankan kepada para penstudi hukum dalam pembahasan Pancasila sebagai cita hukum tidak hanya terbelenggu dengan pembacaan Pancasila dengan konsep hirarkis piramida yang secara ontologi, epistemologi dan aksiologi terpengaruh cara pandang postivisme hukum (hukum barat), tetapi membuka diri terhadap pembacaan Pancasila dengan konsep "berthawaf" atau melingkar yang pemahaman konsepnya lebih cair.

6) Disarankan perlu penghargaaan resmi dari negara terhadap Sultan Hamid II sebagai perancang lambang negara atau setidak-tidak pengakuan resmi melalui pernyataan Kepala Negara Republik Indonesia atau melalui lembaga yang bewenang di hadapan publik Indonesia, bahwa yang merancang Lambang Negara adalah Sultan Hamid II sebagai apresiasi negara terhadap hak moral Sultan Hamid II sebagai anak bangsa. 


\section{Daftar epustakaan}

\section{Buku}

Bakker SJ., J.W.M. Filsafat Kebudayaan, Sebuah Pengantar, Yogyakarta: BPK Gunung Agung Mulia dan Kanisius, 1990.

Barber, C.L. The Story of Language, London: The Chaucer Press 1972.

Bastomi, Suwarji. Seni dan Budaya Jawa, Semarang: IKIP Press, 1992.

Barthes, Roland. Element of Semiology, New York: Hill and Wang, 1984.

Budiman, Kris. Semiotika Visual, Yogyakarta: Yayasan Seni Cemeti 2003.

Budiono, Herusatoto. Simbolisme Dalam Budaya Jawa, Yogyakarta: PT Hanindita, 1988.

C.A., Van Paursen. Strategi Kebudayaan. Terjemahan Dick Hartono Yogyakarta: Kanisius, 1988.

Campbell, Henry Black. Black'k Law Dictionary. ST. Paul Minn: West Publishing. CO, 1979.

Cunningham, Adrian. The Theory of Myth, London: Sheed and Ward, 1973.

Eco, Umberto. A Theory of Semiotic, USA: Indian University Press, 1992.

Fiske, John. Cultural and Communication Studies, Yogyakarta: Jalasutra 2004.

Fromm, Erich. "The Nature of Symbolic Language". Arthur M. Eastman (Ed.). The Norton Reader. An Anthology of Expository Prose. New York: Norton and Company, 1978.

Hamidi, Jazim. Hermenuetika Hukum, Yogayakarta: UUI Pres, 2005.

Hidayat, Rahayu Surtiati. Semiotik dan Bidang Ilmu, dalam semiotika Budaya, disunting T. Christomy \& Untung Yuwono, Jakarta: Pusat Penelitian Kemasyarakatan dan Budaya Direktorat Riset dan Pengabdian Masyarakat Universitas Indonesia, 2004.

Gadamer, Hans. Truth and Method, terjemahan oleh Ahmad Sahidah, Kebenaran dan Metode, Pengantar Filsafat Hermenuitika, Yogyakarta: Pustaka Pelajar, 2004.

Glorier. Incorporated, International Encylopedia, New York, Vol. 7, 1972.

Gordon N, Geoerge. The Languages of Communication, New York: Hasting House Publishers 1969.

Hardjowirogo, 1983. Manusia Jawa, Jakarta: Yayasan Idayu, 1983.

Hockett. George Herbet Mead, Charles. F. A Course In Modern Linguistis. New York, The Macmillan Company, 1958.

Kartohadiprojo, Soediman. Pancasila Sebagai Pandangan Hidup Bangsa Indonesia, Bangsa, Jakarta: Gatra Pustaka, 2009. 
Peirce, Charles Sanders. Logic and Semiotics The Theory Of Signs, 1955.

Piliang, Yasraf Amir. Hipersemiotika; Tafsir Cultural Studies Atas Matinya Makna, Yogyakarta: Jalasutra, 2003.

Sastraprasedja, M. "Pancasila Sebagai Ideologi Dalam Kehidupan Budaya", 1992

Sibarani, Robert. Hakekat Bahasa, Jakarta: PT Aditya Bakti, 1992.

Susanto, Anton F. Semiotika Hukum Dari Dekontruksi Teks Menuju Progresivitas Makna, Bandung: Refika Aditama, 2010

------------------, Dekontruksi Hukum Eksplorasi Teks dan Model Pembacaan, Yogyakarta: Genta Publishing, 2010.

Syamsuar, Zumri Bestado. Dua Sayap Demokrasi, Pontianak: Romeo Grafika, 2002.

Thomas, Jhon B. Studies In The Theory of Ideologi Polty, London: Oxford Press, 1985.

Yasni, Z. Bung Hatta Menjawab, Cet. Ketiga, Jakarta: Gunung Agung, 1980.

Zoest, Aart van. Semiotiek. Belgia: Basisboeken/Ambo/Baarn, 1978.

\section{Tesis}

Turiman, Sejarah Hukum Lambang Negara Republik Indonesia, Tesis, Program Pasca Sarjana Ilmu Hukum, UI, Jakarta, 1999.

Zumri Bestado Syamsuar, Pandangan Paul Ricoeur Mengenai Ideologi dan Kritik Ideologi Atas Teori Kritis Masyarakat, Tesis Magister Ilmu Filsafat, Jakarta: Program Pascasarajana Ilmu Filsafat Fakultas Sastra Universitas Indonesia, Jakarta, 2004.

Anshari Dimyati, Delik Terhadap Keamanan Negara (Makar) di Indonesia: Suatu Analisis Yuridis Normatif pada Studi Kasus Sultan Hamid II, Tesis Magister Ilmu Hukum Universitas Indonesia, Jakarta, 2012

\section{Makalah}

Alqadrie, Syarif Ibrahim. "Kesultanan Qadariyah Pontianak: Perspektif Sejarah Sosiologi Politik", Kertas kerja ini disampaikan kepada para peserta Seminar Kerajaan Nusantara yang diadakan atas kerja sama Pemerintah Kerajaan Pahang dengan Universiti Malaya, Malaysia, di Kuatan, Malaysia, pada 8-11 May 2005.

Pengaruhnya di Nusantara", Hasil Penelitian Sejarah didanai oleh Direktorat Penelitian dan Pengabdian pada Masyarakat (DP3M), Direktorat Jenderal Pendidikan Tinggi (Dirjen), Departemen Pendidikan 
dan Kebudayaan (Depdikbud), RI. Jakarta - Pontianak: DP3M dan UNTAN, 1979.

Turiman. "Lambang Negara Suatu Deskripsi Analisis Dari Sudut Pandang Hukum Dan Kehidupan Kenegaraan", Makalah Diskusi Terbatas Dalam Program Pasca Sarjana Ul Tahun 1995.

\section{Artikel}

Warta Windudarma, No. 224, “Arti Sebuah Simbol”.

\section{Ensiklopedia}

Ensiklopedia Indonesia Edisi Khusus, PT Ichtiar Van Hoeve, Jakarta 1986.

Ensiklopedia Pancasila, 1994.

\section{Website}

Christie Damayanti, megonosangit.blogspot.com "Filosofis Rajawali: Ketajaman Visual dan Kepekaan Hati untuk Kehidupan Kita", dalam <http://www.nature-wildlife -Tawny_Eagle.com>, diakses 11 Februari 2011

Zaini Rakhman/pemerhati elang, penulis buku "Garuda, Mitos dan Faktanya di Indonesia” Pikiran rakyat <http://archive.blogspot.com/2012/09/kisahsang-lambang-negara-burung-garuda>, diakses 11 Februari 2011.

\section{Peraturan Perundangan}

Konstitusi RIS 1949.

Undang -Undang Dasar Sementara, 1950.

Undang- Undang Dasar Negara RI 1945 hasil amandemen II, 2000.

Undang-Undang Nonmor 24 Tahun 2009 Tentang Bendera, Bahasa, Lambang dan Lagu Kebangsaan.

Peraturan Pemerintah Nomor 66 Tahun 1951 Tentang Lambang Negara.

Inpres Nomor 12 Tahun 1968 tentang Ucapan dan Tata Urutan Sila-sila Pancasila. 